\title{
UNVEILING IRANIAN COURTYARD HOUSE: THE EXAMPLE OF KUY-E CHAHARSAD-DASTGAH (1946-1950)
}

\author{
Mohamad SEDIGHI (D) , Dick van GAMEREN \\ Faculty of Architecture and the Built Environment, TU Delft, the Netherlands
}

Received 09 October 2018; accepted 04 April 2019

\begin{abstract}
This article discusses the transformation of the traditional Iranian courtyard house type and neighbourhood structure in the early $20^{\text {th }}$ century Iran, and focuses on the design of public housing in the country's early years of modernisation, after the second World War. It explores how (urban) legislations by Iranian reformists and modernists, and the compulsory unveiling law implemented between 1936 and 1943 contributed to change the image of urban areas and the everyday life of Iranians, particularly in Tehran. While this article provides a short overview of these transformations, it discusses how Iranian architects, educated in Europe, attempted to reconceptualise the ideal form of living, the courtyardgarden house (Khaneh-Bagh), for large-scale housing production, in the country. This article shows how the transformation of this house type became an instrument of accommodating both change and resistance in terms of local customs and habits, in Kuy-e Chaharsad-Dastgah, built between 1946 and 1950 in Tehran. To illustrate these, the design and development of this experimental housing project is analysed in details. It is also demonstrated how this project was developed based on a "planning document" revised by a group of modernist Iranian architects, who intended to improve the hygiene condition of living environments and to accommodate a large number of low-income civil servants in post-World War II, Tehran. It is argued that dual characteristics of the Iranian courtyard house allowed for both incorporating imported models, and simultaneously resisting universalising tendencies towards homogenisation, in the case of Chaharsad-Dastgah.
\end{abstract}

Keywords: courtyard house, public housing, non-Western modernisation, everyday life, Iran, Tehran.

\section{Introduction}

The courtyard house is widely described as an enclosed compound and introverted form that is defineed by "an open court shielded from the outside by the built spaces that surround it." (Rabbat, 2010, p. xxi) Privacy is also described as its vital characteristic, where high walls form an intimate private garden that is accessible from any room of the house (Duncan, 1973). This traditional house type, however, underwent a series of radical changes in the twentieth century Iran under the state's projects of modernisation. These projects started from 1925, when the parliament declared the end of Qajar monarchy, and appointed Reza Khan (1878-1944) as the new ruler, the Shah of Iran (Abrahamian, 2008). After the 1906 Iranian Constitutional Revolution, a power struggle between the Qajar monarch and parliament, and grassroots movements against political scandals and social injustice created a situation that plunged the country into a civil war (Banani, 1961). Reza Shah brought an end to this situation and formed a central government, at the time that radical Iranian reformists pushed for a modern society (Abrahamian, 1982). He launched a socio-political and urban reform programme and took inspiration from his counterpart in Turkey, Mustafa Kemal Atatürk who established the Republic of Turkey in 1923 (Atabaki \& Zuurcher, 2004).

Similar to Atatürk, Reza Shah attempted to reduce the influence of religion and Islamic thoughts in the everyday life of Iranians (Amin, 2002). Reza Shah implemented a compulsory unveiling in 1936, to change women's status in society and to redefine the image of "modern" Iran. He initiated a project of nation building by reorganising traditional urban structure of Iranian cities (Grigor, 2009). This modernisation plan had a large impact on the transformation of street patterns and the expansion of administrative buildings and luxury residential apartments for the elites (Marefat, 1988). Processes of urban transformation led to a large relocation of the urban poor towards cities' outskirts; and it caused the expansion of scattered settlements

${ }^{*}$ Corresponding author. E-mail: S.M.A.Sedighi@tudelft.nl 
in and around urban areas, mainly in the capital city, Tehran (Madanipour, 1998).

The urban transformation of Tehran gained a new momentum when a group of Iranian reformists dominated the four parliaments between 1941-1953 (S. M. Habibi, 1999). They gained political self-determination to rule the country, and undertake a project of modernisation that would involve utilising modern laws and rules, as well as the increase of urbanisation (Kiani, 2013). During this period of time, shifts in the everyday life of Iranians came from the construction of new residential neighbourhoods, in particular for the urban poor and low-income civil servants. In fact, the two major motivations for emphasising the development of housing were to improve hygienic conditions and to accommodate a growing population (Adjdari, 1946c).

In what follows, we aim at contributing to the discussion on the evolution of housing paradigms in Iran between 1941-1953. We look into a particular case of public housing, Kuy-e Chaharsad-Dastgah (Figure 1), to investigate the resonances between the modernisation of Iran and the transformation of vernacular patterns of inhabitation. Through archival studies, we will analyse the typological and morphological aspects of the project and combine the results of this study with the outcome of a site survey in the housing district and interviews conducted with some of its current dwellers. This methodological approach aims at expanding current scholarship on Iran process of urban transformation.

\section{Urban transformation in Iran: a short review}

While Iran's process of (urban) modernisation has been studied from various perspectives, there is little information available on how public housing can be seen as an instrument of the state-initiated modernisation programmes. Scholarly debates mostly address themes such as nation-building, domesticity and home culture, and the relation of modernity and tradition as well as its impact on urban development, triggering a critical understanding

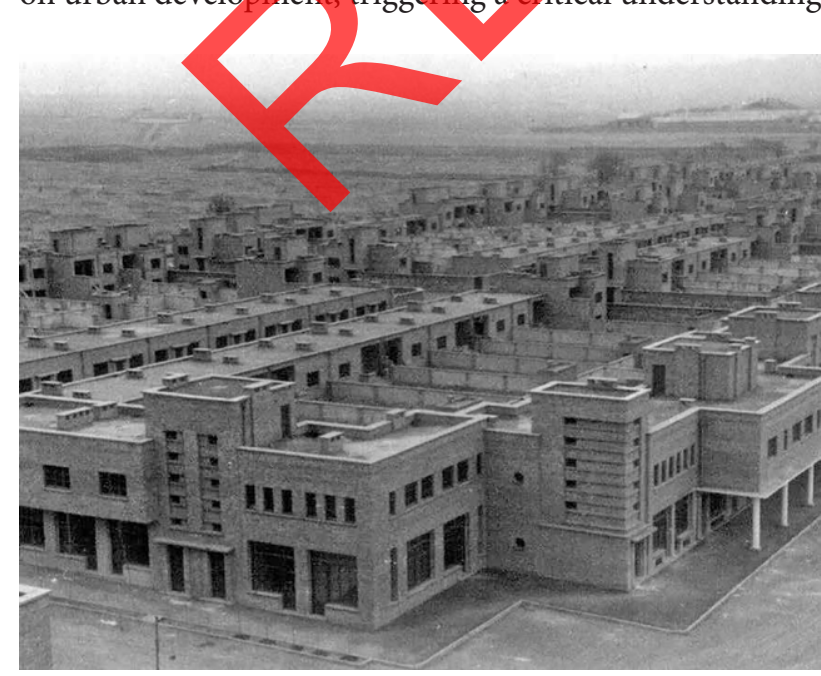

Figure 1. Kuy-e Chaharsad-Dastgah after its completion in 1950 (source: Ali Akbar Sadegh's Family Archive) of some of the most important events in Iran's process of modernisation.

Mina Marefat (1988) studied urban transformation of Tehran between 1921-1941, a period when Reza Pahlavi orchestrated a radical modernisation project, in the country. She argued that the state imposed a gridiron urban pattern and used the construction of administrative buildings as a tool to renew the image of Tehran, from a traditional Islamic city into a quasi-European capital. She also identified how both foreign and native architects became involved in the development of new state institutions such as ministries, banks, and museums. Then, she claimed that the architectural principles employed for the design of these buildings were a strategy to disseminate the ideology of modernity based on a narrative of pre-Islamic Iranian history. In her analysis, she showed how architectural models of most monuments of the pre-Islamic Achaemenid and Sassanid empires formed a basis for the design of many governmental buildings. In this way, as Marefat argued, Reza Shah aimed to recall the grandeur/power of the ancient Persian empire for reconstructing Iranian identity and promoting nationalism and secularism. Moreover, Marefat showed that the architecture of dwelling became a tool of elite Iranians for implementing changes in their lifestyles; and she observed that the elites and the privileged commissioned modernist Iranian architects, especially the ones who educated in Europe, for the design of luxury villas and private residential buildings in the newly developed areas of Tehan, aiming to pursue a "modern" lifestyle.

Talinn Grigor (2009) took one step further to elaborate Iran's history of modernisation through the lens of architecture. In her analyses, Grigor showed that the Pahlavi regime (1925-1979) used architecture as a major political tool for re-appropriating Iranian cultural heritage alongside secular reforms. She examined the role of the Association of National Heritage in promoting a distinct architectural modernity based on Iran's pre-Islamic history. Then, Grigor showed how the Association became an instrumental organisation for embracing Iran's epic cultural history and its penchant for progressiveness by adapting pre-Islamic archetypal models to modernist principles. For instance, Grigor portrayed the Ferdowsi mausoleum as a representative model, where the building functions as a booster of national pride with its pre-Islamic design and ornamentations, while the landscape around the building fabricated a sense of modernism by becoming a touristic place.

Next to the cases mentioned above, the impact of modernisation on the development of urban regulations, architectural pedagogy, urban planning strategies, and architectural design, in the twentieth century Iran has been also studied and published in English by architectural historians such as Ali Madanipour (1998) and Mohammad Gharipour (2016). There are also some important contributions to this debate that have only been published in Persian, by scholars such as Mostafa Kiani (2013), Seyed Mohsen Habibi (1999), and Eskandar Mokhtari Taleghani (2011). Among these scholarly materials, some researchers also focused on the specific case of Chaharsad-Dastgah. 
They described this residential district as a primary attempt to promote Western lifestyles among ordinary Iranians, and to institutionalise change in the tradition of housing design and production. In one of the early studies on the theme of urban change, the socio-urban transformation of the capital city in the 1930s was discussed; and its impact on creating a new urban landscape in Chaharsad-Dastgah was examined (e.g., Karimi, 2013). In other studies, the importance of this transformation was highlighted for neutralising the socio-political life of an emerging middle-class in Iran; and it was shown how the creation of this residential neighbourhood formed a basis for promoting domestic reform and institutionalising new urbanity, in Tehran (Khosravi, Djalali, Marullo, Frausto, \& Riedijk, 2017). In a more recent study, Rana Habibi (2017) discussed the institutionalization of modern middle-class neighbourhoods in Tehran by analysing the Case of Chaharsad-Dastgah. She discussed the urban layout of this project and compared it with that of Abadan, a company town designed by the Anglo-Iranian Oil Company in south-west Iran. It was also argued that the urban layout of Abadan, based on Ebenezer Howard's Garden City ideals, and its housing model became the source of inspiration for designing ChaharsadDastgah. The study also showed that the model of Chaharsad-Dastgah incorporated some typological elements of local architectural culture, and Abadan was a "reference" for Iranian architects to promote new lifestyles among middleclass Iranians, in Tehran.

Despite a growing wealth of architectural scholarship on Iran's process of modernisation in general, and on the case of Chaharsad-Dastgah, in particular, the authors mentioned above have addressed the architecture of dwelling as a static phenomenon, mainly attached to a specific social, political and economic circumstance. Most of the research referenced earlier overlooks the agency of the dweller in the transformation through time of public housing districts; and there are little studies discussing how planning and urban design strategies in post-1941 Iran contributed to the evolution of housing paradigms in the country. This article, therefore, will discuss the extent to which Chaharsad-Dastgah was used by a group of young-leading Iranian architects as a tool to influence daily life practices through transforming the traditional courtyard housing typology and traditional neighbourhood planning structures. To create a clear backdrop to the context in which this case study was developed, we need to understand the development policies, first, undertaken by Reza Shah between 1925 and 1941, and then, by reformist Iranians after his abdication in 1941.

\section{Spaces of socio-political transition}

The reign of Reza Shah can be seen as a transitional phase that tied the modernisation of Iran to the everyday life of ordinary people (Ansari, 2003). Reza Shah's modernisation project was largely based on implementing a radical reform in both the areas of urban design and social policy. This can be understood from his inaugural speech, where the Shah argued that "we will convert Iran into a European country... and Tehran will be the first modern city in the country to serve as a model for other Iranian cities." He emphasised that "in keeping with the morality of Iran, let us hold this sentence in mind as our guideline that Iran should become mentally and somatically, outwardly and inwardly European-oriented." (Arin Pour, 2000, p. 24). Thus, the Shah's intention for modernising the nation was Western-oriented, and included a transformation programme for changing traditional urban fabric of Tehran and reorganising traditional structures of society.

Reza Shah's social reform took place in the form of a secularisation project, aiming to reduce the influence of religion on the everyday life of Iranians. As the first step, an educational reform was undertaken under the newly established Ministry of Education. By introducing a new educational system based on the French model, this ministry marginalised traditional schools that educated children based on Islamic thoughts (Catanzaro, 2014). Further, a professional teacher-training programme was conducted by the ministry, and a new educational infrastructure was conceived as primary, secondary, and technical schools. ehran University was established in 1935, and a group of students were despatched to European universities.

Shah's secularisation project focused on women's status in society. His visit to Atatürk in Turkey in 1935 deeply influenced the Shah, in particular regarding the role of women beyond the realm of home (Cronin, 2003). Upon his return, Reza Shah claimed that for making progress and developing this country, the significance of women's participation in societal activities cannot be overlooked. Under what he called "Awakening" for Iranian women, Reza Shah launched a reform project in 1936, where the expansion of women's work, education, and civic presence held a dominant place. In line with the Shah's intention for making the nation both outwardly and inwardly European-oriented, changing the appearance of Iranian women became a core of his reform project. Reza Shah saw veil (Hejab) as a sign of "backwardness" and as a restriction for women's involvement in public activities (Rostan-Kolayi \& Matin-Asgari, 2014). As a result, a compulsory unveiling was implemented to redefine the image of "modern" Iranian women in society, and female members of households were forced to appear in public spaces, unveiled (Amin, 2002).

Refining the image of "modern" Iran was not limited to unveiling women. All adult men, with the exception of state-registered clergymen, were required to wear Western-style trousers, coats, and Pahlavi hat, a strategy that aimed to "standardise and Europeanise the appearance" of the nation (Houchang E. Chehabi, 1993, p. 209). Further, a civil legislation act was approved that required the registration of all marriages and divorces, and only allowed girls to get married after the age of fifteen (Hoodfar, 2000). Arguably, these changes, particularly in literacy level and women's freedom, facilitated the engagement of non-elite Iranians in state-led socio-political and economic activities. This formed a basis for the emergence of 
the Iranian middle-class, in the late-1930s (Gastil, 1958), where government employees, teachers, and non-bazaar merchants largely formed the body of this new urban class (Houchang E. Chehabi, 1993).

Changes in urban lives were also promoted through an urban modernisation project, and Tehran served as a pilot model. The Shah appointed General Karim Bozarjomehri, his closest friend in the army, as the head of the Municipality: the mayor of Tehran (Madanipour, 1998). In the early years of its establishment, the Municipality was only responsible for cleaning and paving the streets (Nilghaz, 2009). Under the leadership of Bozarjomehri, however, Tehran Municipality became a main agent of both urban governance and development from the 1930s. To expand the urban structure of the city and to give more room to new urban projects, the Municipality, first, demolished Tehran's city walls (Grigor, 2014). Then, the Municipality published a planning document in 1933 including a set of urban regulations, which might be seen as the first 'modern' urban planning tool in the country. Known as the Act of Developing and Widening Streets, this document mainly focused on the transformation of street-profiles, which gave birth to a Haussmannian urbanism over traditional neighbourhoods in Iran, under the reign of Reza Shah (Kiani, 2013).

\section{Unveiling the traditional urban structure of Tehran}

The planning document for Tehran was largely designed by a young modernist architect, Gabriel Guevrekian. To prepare a plan for the transformation of the city fabric, the mayor Bozarjomehri sought for Western urban planners and architects. In his visit to Europe, he met Guevrekian, who studied architecture in the Vienna's Academy of Applied Arts, under the supervision of Josef Hoffmann and Oskar Strnad. Bozarjomehri asked Guevrekian to become the chief architect and city planner of the municipality of Tehran, an opportunity for the young architect to implement his ideas, in a large scale (Khosravi, 2015). In the beginning of his career, Guevrekian was actively involved in the early stages of the CIAM congresses where he served as the general secretary between 1928 and 1933 (Mumford, 2000). Indeed, his association with the European circle of avant-garde architects such as Henri Sauvage and Le Corbusier made him the representative of the modern international movement in Iran. This happened when he arrived Iran in 1933 on the government invitation to develop an urban plan for Tehran (Grigor, 2014).

The execution of the planning document and new street layout radically changed the structure of traditional neighbourhoods. The document was a descriptive text, in three pages consisting of ten articles and five notes. It focused on the improvement of street-profiles, and the reconstruction as well as reorganisation of façades alongside streets. Arguably, the emphasis on the design of façades might be seen as an attempt to regulate the image of streets and promote change in the relationships between public and private spaces in the new urban plan for Tehran. The document provided a juridical and financial mechanism to allow the Municipality for implementing changes within the existing urban fabric. It also highlighted the importance of preparing a municipal street layout for the urban areas where the new legislation should be implemented.

In 1937, the Municipality proposed a new urban layout for Tehran that was influenced by the modernist design principles discussed in the early CIAM congresses, traceable from its gridded system of streets and rigid zoning (S. M. Habibi, 1999). In this plan, traditional neighbourhoods were divided in smaller segments and bounded with a set of streets, forming new residential sectors in Tehran. Further, the set of regulations provided by the planning document led to the development of some new building typologies, such as residential blocks, offices and commercial buildings, alongside the newly established streets (Figure 2). The street facades, expectedly, were designed based on the planning documents, which specified large openings (i.e, windows, balconies, loggias). In so doing, interior private spaces were largely exposed towards public spaces, forming an unveiled urban image for the city.

As observed by Mostafa Kiani (2013), Reza Shah's urban and architectural projects became a tool to unveil, extrovert, and control the socio-spatial structure of traditional neighbourhoods. At the same time, these new projects formed a basis for establishing a nationalist and bureaucratic bourgeoisie political system, especially hrough the expansion of new administrative, financial, and governmental buildings, such as new ministry buildings, municipal/post offices, and banks. This explains why most state's financial resources were devoted to the urban development of Tehran, and many European-educated Iranian architects became involved in designing statefunded buildings, based on a new approach to the preIslamic Persian architectural styles. This approach can be seen from Mohsen Foroughi's design for Iran's National Bank, showcasing a mixture of pre-Islamic Persian and European neo-classical style (Figure 3).

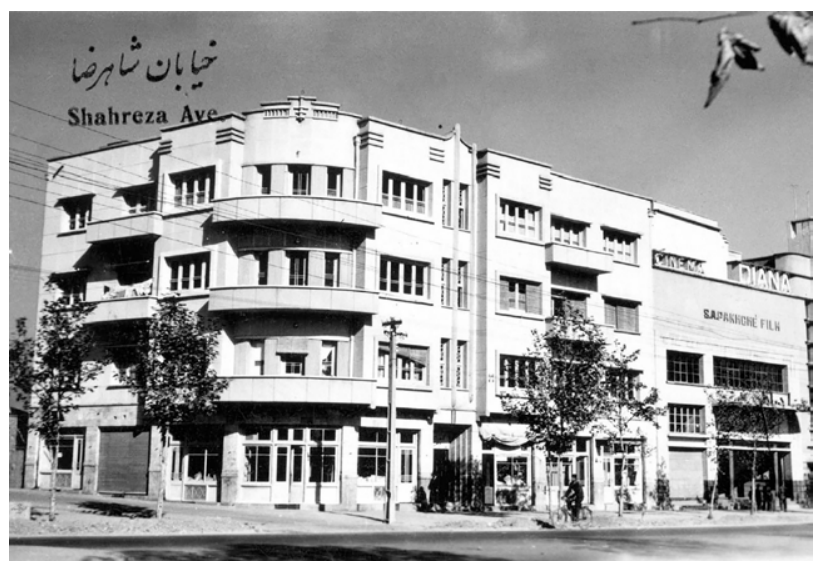

Figure 2. Shah-Reza (Ferdouwsi) street in 1940s Tehran accommodating new building typologies such as multi-story residential buildings and offices and shop-stores (source: Iranian Historical Photographs) 

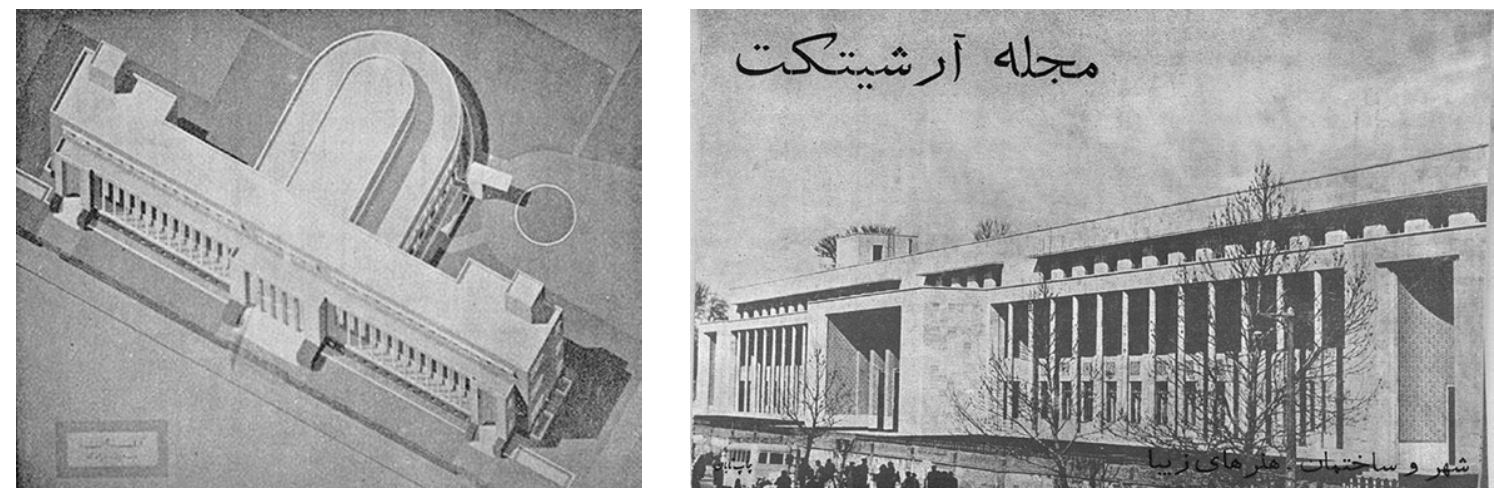

Figure 3. The National Bank of Iran (Bank-e Meli Iran), designed by Mohsen Foroughi, with a mixture of pre-Islamic Persian and European neo-classical style (source: Arshitekt no 6 (1946): cover-page)

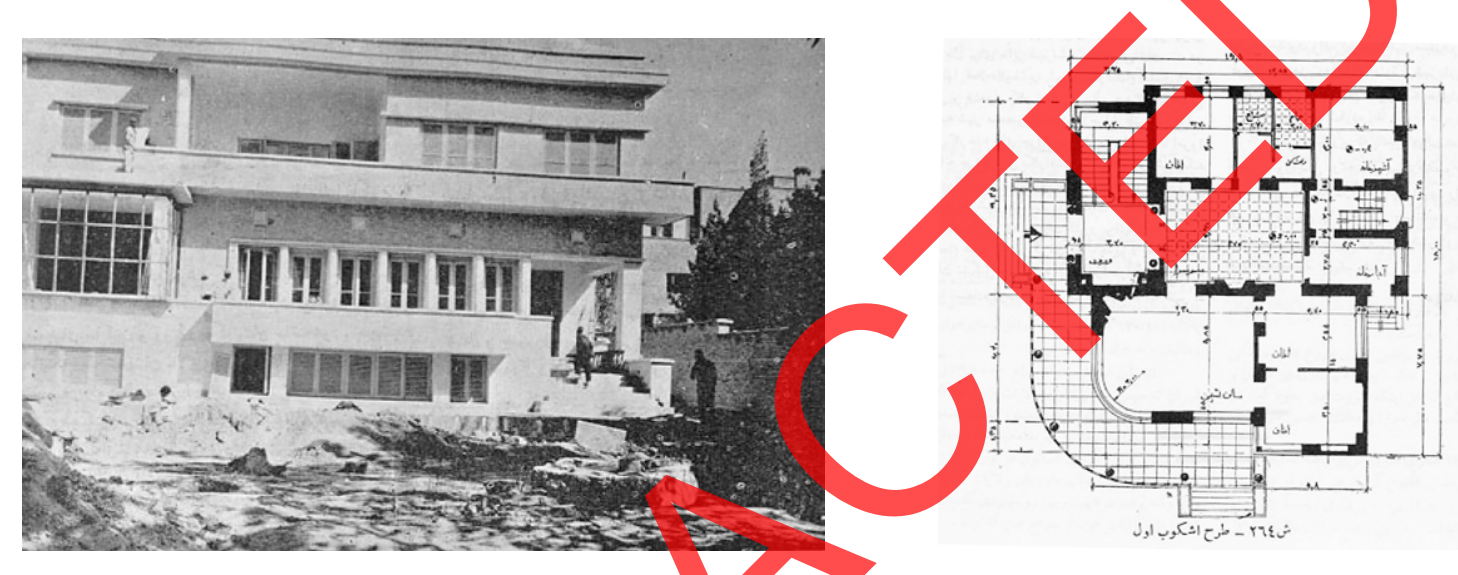

Figure 4. An examples of luxury villas designed by modernist Iranian architects for their rich clients, in the 1930s Tehran (source. Arshitekt, (5) (1946), 170, 176)

This modernisation plan also impacted the life of privileged Iranians. In most non-governmental projects, such as luxurious residences and lavish villas, avant-garde architects employed modernist design principles such as abstract forms and minimalistic aesthetic (Figure 4). They received these private commissions by rich clients who have already been in contact with the West (Europe and north America), and aware of some new architectural movements in Europe (Bani Masoud, 2015). On the contrary, the new middleclass groups and ordinary people continued building their houses based on traditional techniques and principles. Nevertheless, this situation began to change with the establishment of the Mortgage Bank (Bank-e Rahni) by the government in 1939. This state-led institution became responsible for financing the building of state-initiated housing projects and providing long-term loans with low interest for lowincome families. But, in the absence of any planning for housing development, the Mortgage Bank was not able to carry out construction projects.

\section{Designing housing policies in early-1940s, Iran}

In the early-1940s, the government was comprised of a group of Iranian reformists/modernist, who appointed Ahmad Qavam as the primer-minister of Iran. Indeed, Qavam was an influential reformist that played an instru- mental role in drafting the first constitutional law, after the 1906 Constitutional Revolution (Abrahamian, 1982). While the administration of Qavam sustained Reza Shah's reform programme and his bureaucratic apparatus as essential tools for modernising the nation, it sought to implement an array of welfare benefits for the emerging middle-class (Abrahamian, 2008). Qavam's administration lay a distinct emphasis on the involvement of women in both economic and social activities (Moghadam, 2006). It comes, thus, as no surprise to see that the compulsory unveiling law lasted until the end of Qavam's first administration in 1943. Moreover, his administration approved the provision of pensions for government employees and interest-free loans for housing low-income civil servants. This explains why the construction of affordable housing gained a prominent place in Qavam's social modernisation plan. The Mortgage Bank was assigned to deliver needed financial means for constructing new houses, and to plan for housing development, with the Municipality of Tehran.

In fact, the urgent need for constructing affordable housing was a side-effect of Reza Shah's urban transformation programme. This led to the expansion of Tehran, and caused a massive rural-urban migration. As a result, urban population density of the capital grew drastically, bringing about a housing crisis. As described in the pages of the first and only Iranian architecture journal in the 1940s, 
Arshitekt, overcrowding and over-population, as well as insufficient access to sanitation and clean water at household level exacerbated poor living conditions of many Iranians in the cities (Adjdari, 1946a). One of the sharpest reviews was provided by Vartan Hovanesian (1946), reporting that "many children would die every day in those chaotic, contemptible and dirty places, lacking suitable light and fresh air; these unhealthy conditions would gradually and cruelly break the spirits of these young people and would penetrate into and poison each of their cells. It is a gradual death, it is a crime." (pp. 139-140) Indeed, it was within this context that many Iranian modernist architects began to discuss new models of urbanism in Iran, and to propose solutions to housing problems, especially in Tehran.

In the pages of Arshitekt, the company town of Abadan, in south-west Iran, received a great deal of attention. Constructed by the Anglo-Iranian Oil Company, later British Petroleum, Abadan made use of "the most advanced technology and the best infrastructural elements, including a sewage system, electricity, air conditioning, running water, and kitchen appliances." ("Abadan: Az Nazar-e Sakhteman va Shahrsazi," 1946). Designed by BP’s architect, James M. Wilson in the early-1920s, Abadan was based on Ebenezer Howard's Garden City concept, and on three housing typologies: one-storey row-housing for workers, semi-detached houses in one or two-storey for mid-tier employees, and spacious bungalow villas for British expatriates (Crinson, 1997, 2003). These features might explain why Abadan was described by Arshitekt as an ideal model of urbanism for urban development in Iran (Figure 5).

Aside from analysing the housing condition in Abadan, a series of international housing projects were discussed in the Arshitekt. For instance, the root of largescale housing development was traced back to the fifteenth century city of Augsburg in Germany; and projects such as Victoria Town designed by Buckingham in 1849, Hygie designed by Richardson in 1857, and the Garden City of Letchworth designed by Sir Raymond in 1903 were described as early models of low-cost housing in Europe. In these analyses, three conditions were defined as the driving force for the development of a "hygienic", "modern", and "well-organised" city: the planning and design of the entire town, the emphasis on the notion of collectivism

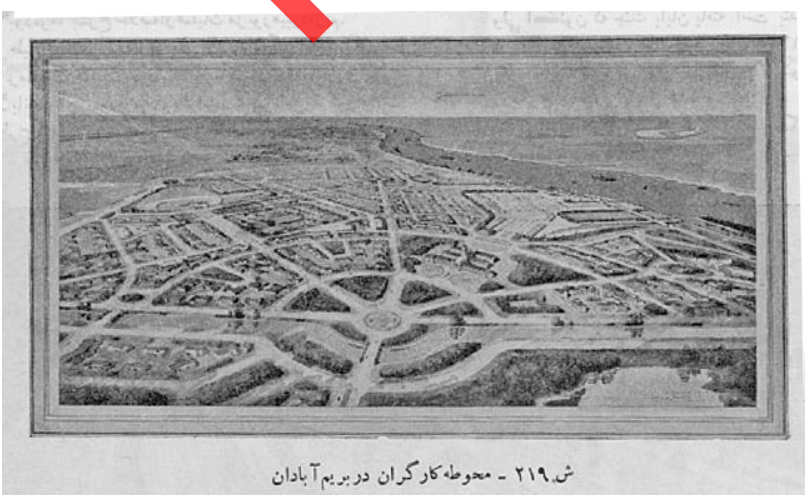

in land-ownership and in societal relations, and the importance of urban regulations for developing new neighbourhoods with well-defined street-profiles, and housing orientations (Khorsand, 1946).

Interestingly, modernist architects, to make Tehran a better place to live, have already put these conditions into practice. As mentioned previously, the 1933 planning document of Tehran mainly focused on the transformation of street-profiles and erection of multi-story buildings. However, since the document did not provide building regulations that were enforced by the authorities, people mostly built their houses with less attention to the provision of natural light and fresh air, leading to the construction of scattered settlements in Tehran (Karimi, 2013). In the absence of Guevrekian who left the country in 1937, a group of European-educated Iranian architects, such as Abbas Adjdari, and Naser Badie, took initiative for improving the planning document, under the leadership of Ali Sadegh. Furthermore, they collaborated with Iraj Shams, the general director of architecture department from Tehran Municipality, to prepare a set of building regulations for the construction of new residential houses and neighbourhoods, in Tehran.

Indeed, these architects were part of the first generation of students who were dispatched to Europe under Reza Shah's command to study architecture or urban planning/ design at European universities. One of the influential figures of this group was Ali Sadegh, who studied both civil ngineering in KVAB University of Brussels and architecture at École des Beaux-Arts of Brussels between 1929 and 1937. He took inspiration from the works of a group of Dutch modernist architects, De Stijl, who advocated pure abstraction and universality by a reduction to the essentials of form (Marefat, 1988). After his return in 1937, he became an instrumental figure in further developing the 1933 planning document of Tehran with the help of his European educated colleagues. Sadegh became a board member of Tehran's City Council in 1939; and for many years, he acted as the head of the High Council of Architecture and Urban Planning in Tehran, an opportunity that helped him to improve living condition of citizens.

As a first step, these architects revised and expanded the planning document of Tehran, in 1941. Known as the

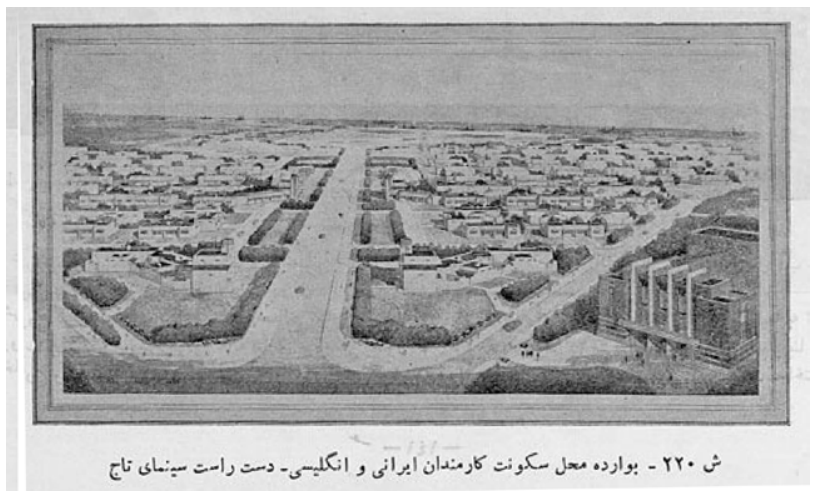

Figure 5. Abadan was depicted in the pages of Arshitekt as a city with well-organised streets, with green lanes and parks, as well as with well-designed residential neighbourhoods (source: Arshitekt, (4) (1946), 141-142). 
Act of Modifying and Developing Streets and Urban Spaces, this document formulated a set of urban and building regulations with 18 articles, and 12 notes, where three articles specifically explained the condition of issuing building permits in Tehran. As indicated in this document, the building permit would only be issued, if the Municipality of Tehran approved the design documents; thus, a supervisory role was defined for the municipality during the construction process. The document was approved by parliament in 1942, and formed a basis for arranging the internal organisation of houses, especially regarding the access of all habitable rooms to natural light and fresh air. This situation was very critical in the existing settlements in Tehran; so, the aim of the document was to assure a minimum hygiene condition for developing residential neighbourhoods and living environments, in the city.

While Sadegh largely focused on the importance of improving urban and building regulations, Badie pushed for developing an infrastructural plan for Tehran. Naser Badie studied town planning in the Institute d'Urbanism de l'Université de Paris; and since his return to Iran in 1940 , he served as the head of urbanism and urban planning of the Municipality of Tehran. In his serial publications in the Arshitekt, Badie (1946) addressed the importance of mapping the existing urban environments and land-use patterns, especially for preparing a water supply system and sewage network in Tehran. A detailed map of the city was essential for making such improvements, which inspired the founding of Iran's Cartographic Centre. After the preparation of this plan, the municipality asked the London-based engineering company, Alexander Gibb and Partners, already involved in Abadan, to prepare a plan for the water supply and sewage system of the city in the mid-1940s (Roberts, 2006). Interestingly, this sanitation plan later became a point of departure for future development of urban areas in Tehran.

The notion of developing low-cost housing also held a prominent place in the municipal agenda. Since the mid-1940s, modernist architects began to discuss the notion of home and its meaning for developing large-scale housing schemes, especially in the pages of the Arshitekt. For instance, Noureddin Kianouri (1946) reported on the mass housing constructions in East Bloc and SovietRussia, whereas Manouchehr Khorsand (1946) discussed the development of large-scale housing schemes in West Europe. However, it was Mohamad Ali Sheibani, who returned from his studies of low-cost mass housing at École des Beaux-Arts in Paris, France, that received the most attention from the government for his goals of turning affordable housing into a national movement.

Sheibani was a modernist state-architect who cofounded the first state-led construction firms in Iran: Sherkat-e Sakhtemani and Behsaz. He was introduced to the idea of low-cost housing, through a set of discussions on the public works of the French Labour Minister, Louis Loucheur, from a conference held in Switzerland. In his publications, Sheibani attempted to reconceptualise the notion of home for mass production. For instance, in his article: Khaneh-ye Khub (A Good Home), Sheibani drew the attention of decision-makers towards the importance of constructing new houses based on modernist design principles, not only for Iranian elites, but also for the whole society. By labelling low-cost housing as a national movement for stimulating social reform, Sheibani (1946a) claimed that:

"a home is the first building block of a society. A good home is the centre of family and the first training area for children. A good home is comfortable and beautiful place; it is a place for education. A good home is a modern house with large windows that absorb sun in order to maintain healthy citizens. A good home makes intimate families. The person who owns a good house has more passion for his country. A good home is a generous house that bestows happiness and health on its residents. The house that you build today would be an investment for the future of your children." (p. 28) ${ }^{1}$

Sheibani described an ideal home as a "modern" house which would nurture healthy citizens at their country's disposal. It is, thus, not surprising why he urged the government to fund "collective" housing for low-income Iranians as a tool for urban modernisation. In his view, the meaning of collective for the design of housing was simply seen as a way of clustering modern houses based on new urban regulations. This typology, as Sheibani (1946b) pointed out, would facilitate change in everyday socio-cultural practices of citizens in new neighbourhoods, and enable the government to transform the spatial structure of scattered settlements in south Tehran. Arguably, Sheibani conceptualised the notion of "modern" home and "collective" housing as a political instrument, which would help the government to promote new lifestyles among ordinary Iranians.

This model of housing became a source of inspiration for state-led urban development. In 1945, the newly formed cabinet of Prime Minister, Ahmad Qavam, took initiative to draw a seven-year urban reconstruction plan for the major Iranian cities, where the capital city, Tehran, became a pilot model (Adjdari, 1946c). Sheibani from the Ministry of Interior took the leadership to develop this urban plan. The National and Mortgage Bank, together with the Municipality of Tehran became responsible for the preparation of a housing project that would accommodate 1,000 civil servants, within the existing borders of Tehran.

The National Bank and Mortgage Bank took responsibility to provide needed financial means for purchasing land and constructing houses. The Mortgage Bank also became responsible for the construction and supervision of projects. The Municipality had to deliver urban and architectural plans, as well as to provide basic infra-

\footnotetext{
1 This note was first translated by Habibi (2017) and modified by the authors of this paper.
} 
structural facilities, such as asphalted roads and plumbing for drinking water. The municipal architect, Ali Sadegh, was appointed by the Mortgage Bank as the head of the design team. Sadegh collaborated with a group of young European-educated Iranian architects including Manouchehr Khoursand, Hossein Sadegh, and Abbas Adjdari, to develop the project. They co-founded the Association of Registered Iranian Architects in 1946; and they used this opportunity for introducing their ideas into the construction of new neighbourhoods, in Tehran (Marefat, 1988).

\section{Kuy-e Chaharsad-Dastgah}

As part of Tehran's housing programme, the design team proposed a residential neighbourhood in south-east Tehran, an area that later became known as Kuy-e ChaharsadDastgah. The location of the project was just outside the municipal borders of the city. Indeed, the choice of this location was a strategy to reduce the impact of urban landuse and land-price on the development of this low-cost housing project. The first location proposed by the $\mathrm{Mu}$ nicipality for this project was an old ditch, 4-meter deep, at the east border of Tehran. As both filling the ditch and buying land in the city would considerably increase the cost of construction, the Mortgage Bank chose to realise the project outside Tehran (Khoursand, 1946).

The design team selected an area of approximately 19 hectares that was situated in the south of the Doshan

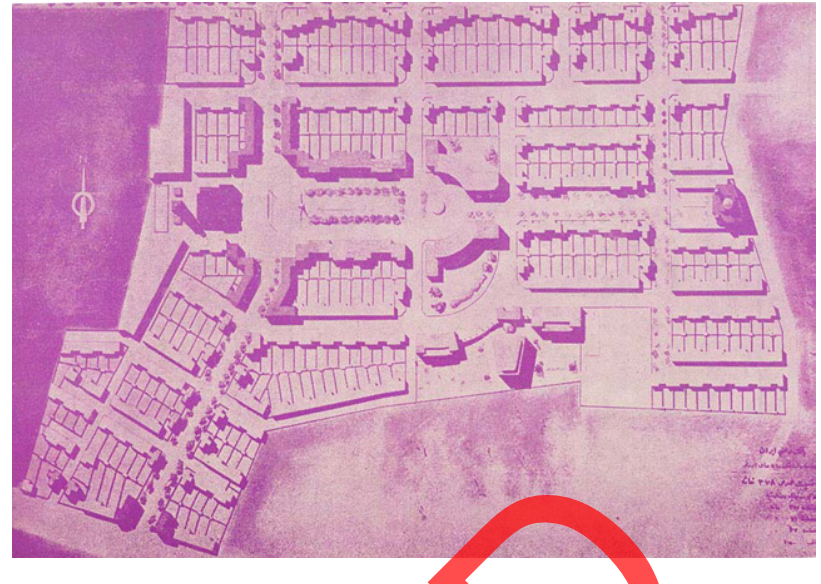

Figure 7. The urban layout of Kuy-e Chaharsad-Dastgah, designed and constructed between 1946 and 1950 (source: Arshitekt, (4) (1946), cover page)

Tappeh road and close to a weapon-factory (Figure 6). This location was part of a larger development plan prepared by the government for constructing a hospital and water storage for Tehran. The existing plans to construct service factities in this area made this site a favourable option for the reducing the cost of extending the city's infrastructure to Chaharsad-Dastgah. The Municipality approved the selected construction plot, and the National Bank dedicated a budget for constructing 400 houses, for the first phase of development. The Mortgage Bank so took responsibility to build the project between 1946 and 1950, and to provide needed building materials such as bricks for load-bearing walls, steel I-beams for slabs, and in-situ concrete for foundations (Mohamad Abadi, 1946). For brick production, the Mortgage Bank established a "Hoffmann kiln" in south Tehran, which would enable the Bank to accelerate the production of houses and ease the impact of material cost on the development of the project. Thus, Chaharsad-Dastgah became the first state-sponsored low-cost housing model in Iran to be designed by a group of European-educated Iranian architects and fully constructed with local materials ("The Overview," 1946).

For designing the urban layout of Kuy-e CaharsadDastgah, the design team employed a system of intersecting streets that combined with an existing diagonal road to divide the construction plot into 25 blocks. The spatial structure of each block was defined by a central void and an enclosure. The void was formed at the heart of each block through the back-to-back aggregation of the individual courtyards. The enclosure was made with dwelling units; and these units were grouped as a set of one- and two-story houses, placed at the periphery of each urban block (Figure 7). This grouping resembled a row typology from the placement of dwellings alongside the streets, with a series of L-shaped two-story residential buildings on the corners to form a perimeter semi-closed urban block typology (Figure 8). In fact, this typology created a continuous facade for the streets, and provided some degree of privacy for the back-to-back organised courtyards.
Figure 6. The location of Kuy-e Chaharsad-Dastgah, in Tehran (1948) (source: the authors) 


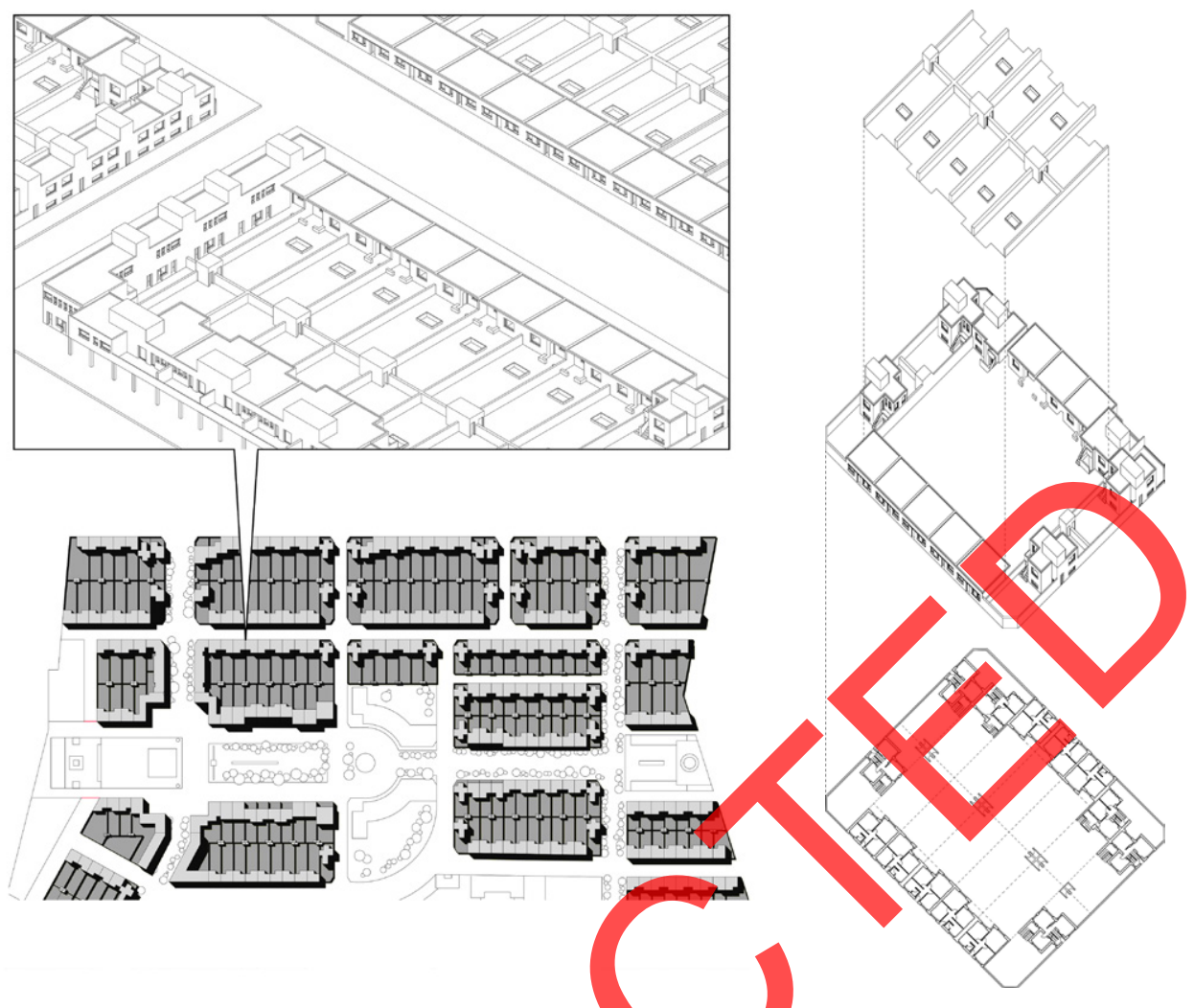

Figure 8. In Chaharsad-Dastgah, each semi-enclosed urban block was created through a combination of row-house and various corner-house typologies (source: the authors)

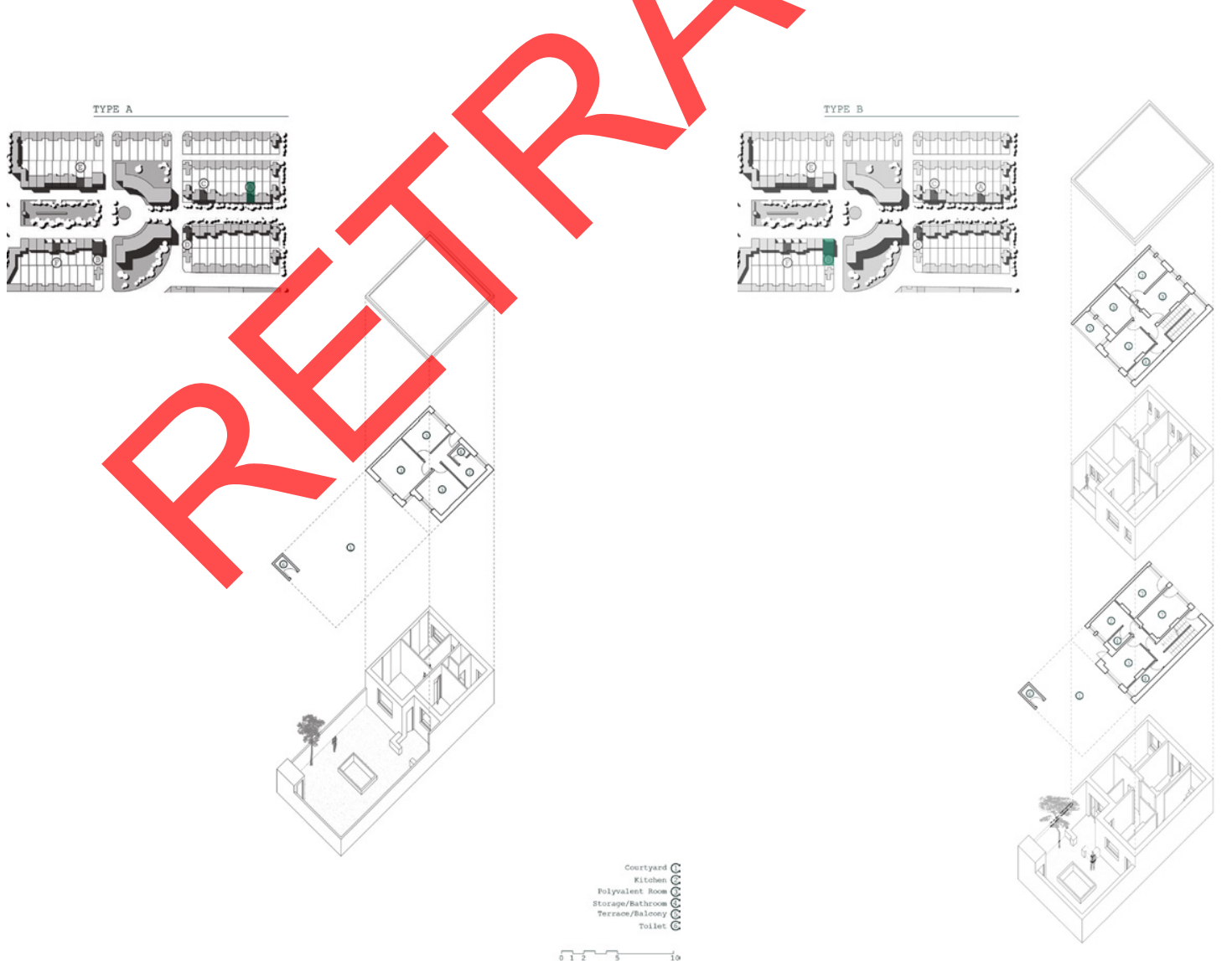



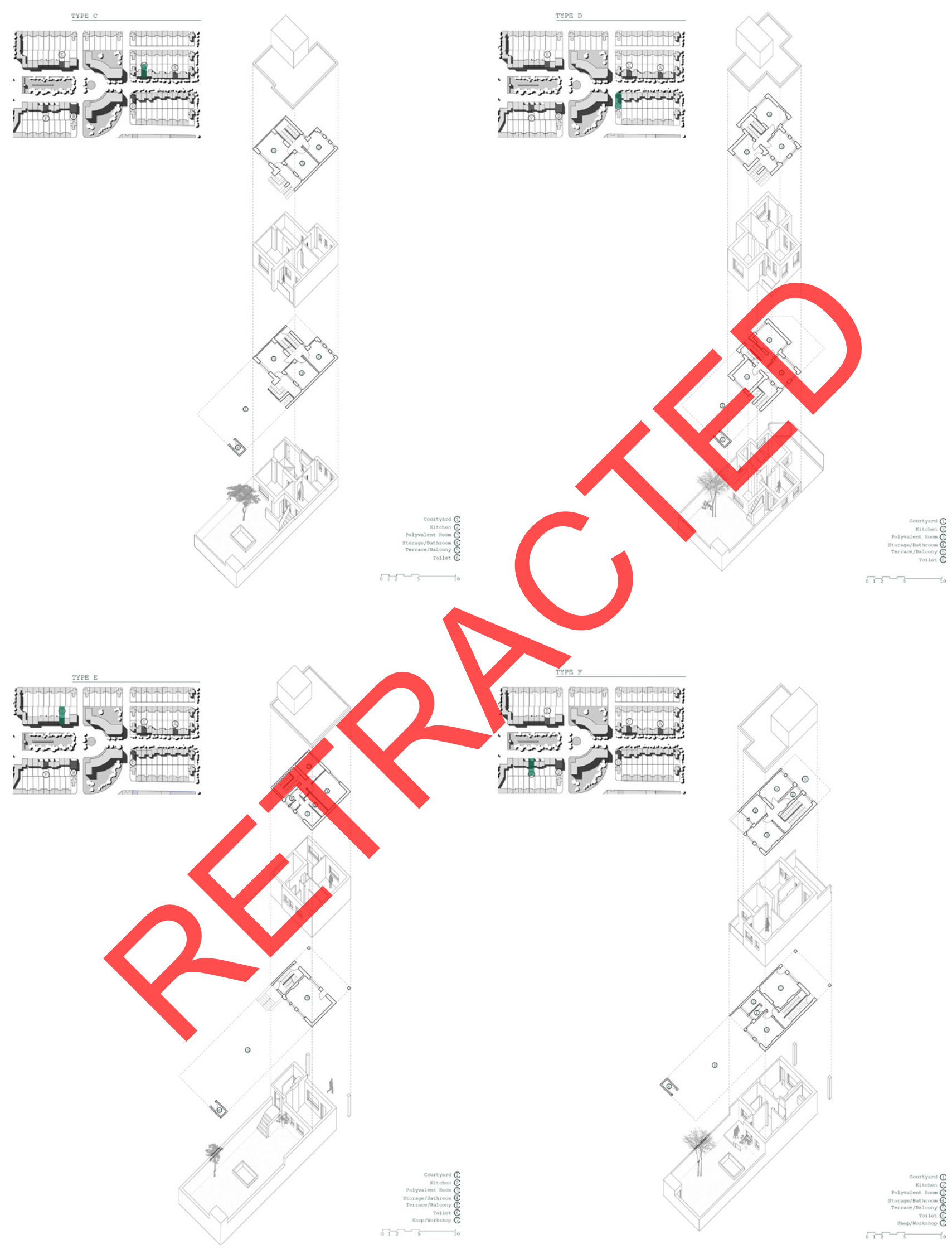

Figure 9. Six main dwelling types were designed for the construction of houses in Chaharsad-Dastgah (source: the authors) 
The courtyards played a vital role in shaping both the urban and dwelling layout. For the design of houses, the architects of Chaharsad-Dastgah proposed dwelling units in two main types: one- and two-storey houses. Each house included necessary service spaces (i.e., kitchen, storage, bathroom, and toilet), and was designed with small variations in size, from 64 to 96 square meters, or in number of habitable rooms (Figure 9). The one-storey houses were designed with either three habitable rooms on the ground level, or with two additional rooms in the basement. The two-storey houses were made up of either three habitable rooms with balconies, placed on top of shop-stores, or a combination of the latter with two additional rooms on the ground level. Known as the corner type, a distinct two-story house was also designed in a L-shape configuration with five habitable rooms as well as with a front and back yard. Moreover, a minimum surface of 80 square meters was provided for each dwelling type as its outdoor room: the courtyard.

These courtyards shared some characteristics with that of the traditional Iranian courtyard-garden house type (Khaneh-Bagh) (Figure 10). In this traditional type, the courtyard included a small garden and it was surrounded with high-walls or habitable rooms. Further, the courtyard was mostly used as a locus of everyday life and practices such as cooking and family gathering, while also providing direct access to all interior spaces of the house ( marian, 1994). The courtyard was connected to the larger body of the neighbourhood through a web of galleries and
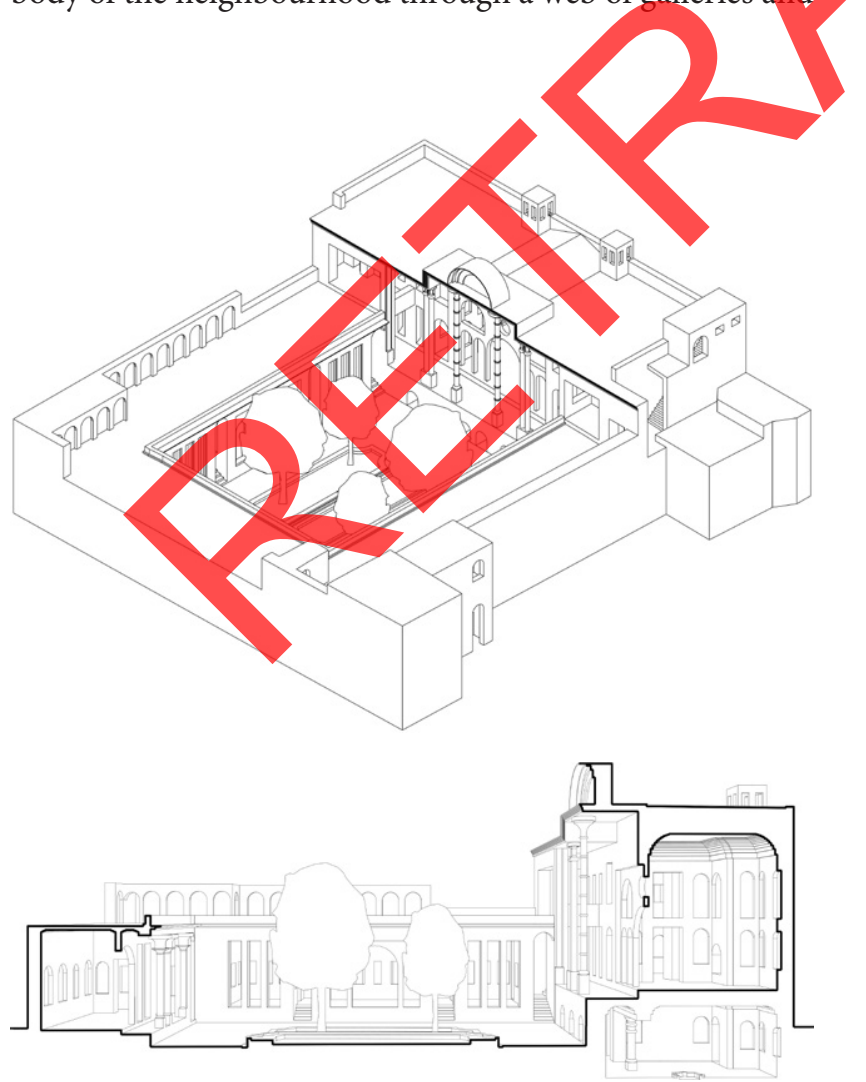

Figure 10. A typical traditional Iranian courtyard-garden house (Khaneh-Bagh) (source: the House of Qavam in Isfahan (Iran), drawn by the authors) corridors, an access network that created the gradation of public-private separation and transition in this traditional type (Figure 11). Arguably, these characteristics can be traced in the houses of Chaharsad-Dastgah, where each courtyard was enclosed with a set of walls and habitable rooms. In this project, while all living areas were placed on one side of the courtyard and towards the streets, some service spaces were designed on the opposite side, and only accessible through the courtyard. Moreover, each courtyard was connected directly to most interior rooms, and to the public space through a web of corridors.

Aside from the streets, the designers of ChaharsadDastgah proposed a central spine as the main public space of their project that aceommodated needed public amenities for future inhabitants. This neighbourhood centre included a plaza, a roundabout, and two communal gardens, and it was connected to the surrounding urban blocks through two parallel boulevards that perpendicularly crossed the central spine. Offices and administrative buildings such as the police station and municipal buildings were grouped in and around the plaza. The gardens were surrounded with shops; and some public buildings such as a school, clinic, bank and post-office, that were placed around the roundabout to frame a playground for children. Most workshop spaces were designed alongside the boulevards, while water-storage and a small mosque were placed to anchor the two ends of this central spine (Figure 12).
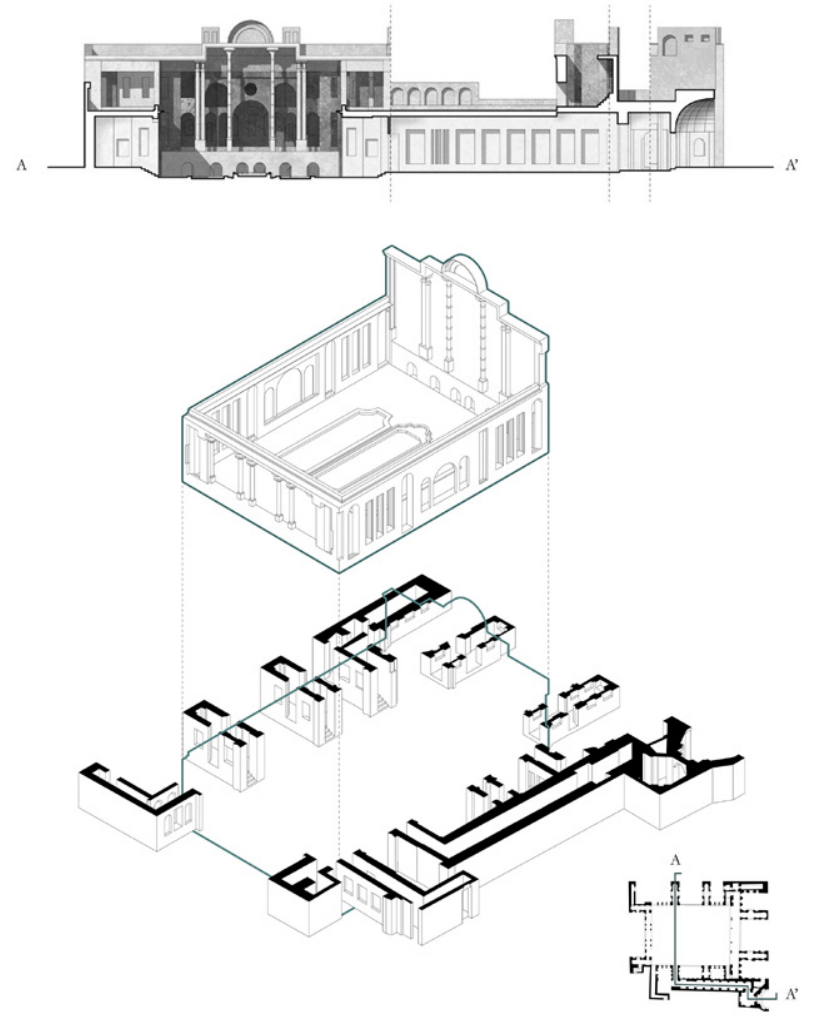

Figure 11. The position of a courtyard house and its system of access in the larger body of a traditional neighbourhood (source: the authors) 


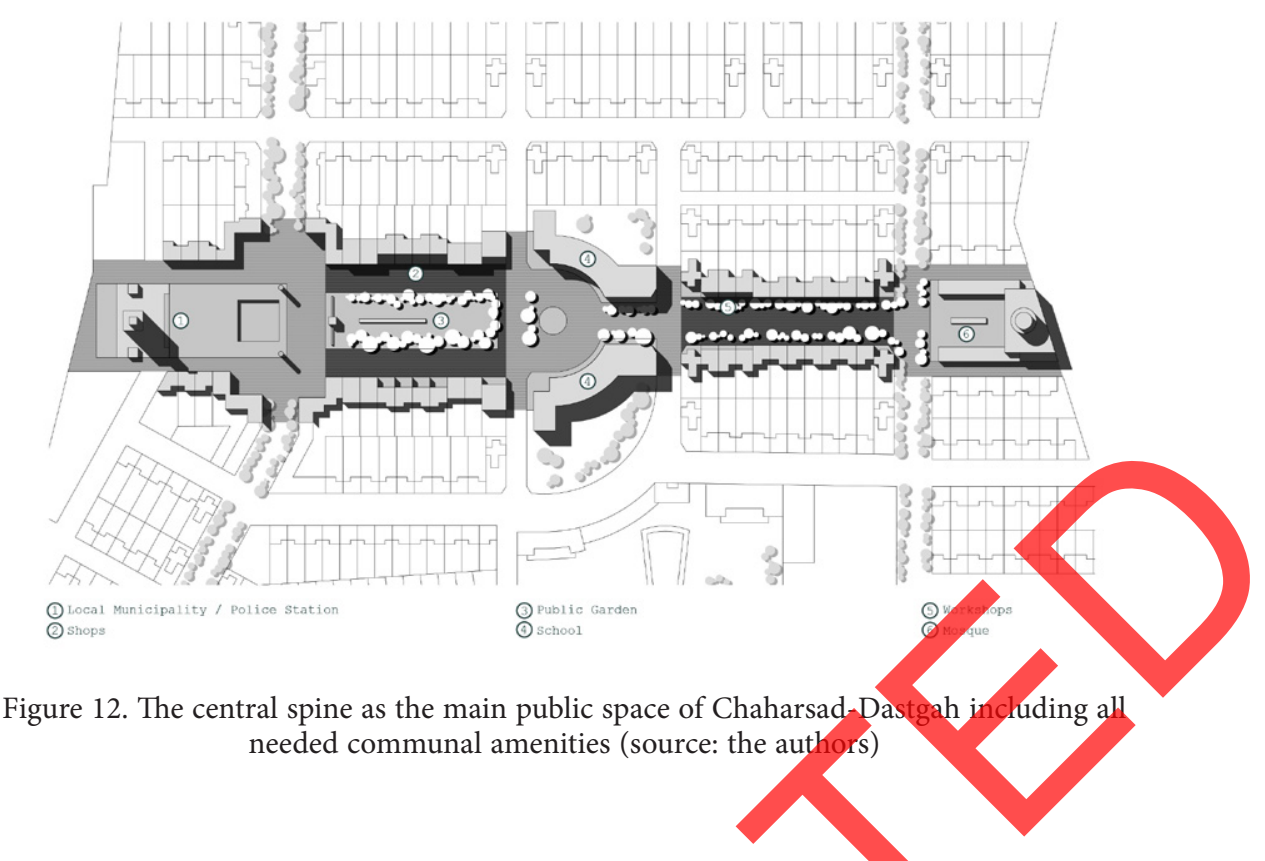

Some similarities might be found between the spatial layout of Kuy-e Chaharsad-Dastgah and that of Abadan. As mentioned earlier, Abadan was often praised in the pages of Arshitekt for providing needed infrastructure such plumbing and electricity, improving the hygiene condition of living, and creating new leisure facilities such as parks and gardens for the residents of Abadan. It comes, thus, as no surprise to see that the architects of Chaharsad-Dastgah also published detailed reviews on the infrastructural, hygienic, and spatial features of their urban model in Tehran, and discussed both Abadan and Chaharsad-Dastgah as the perfect manifestation of new urbanism in Iran. This comparison could also be found in the works of some architectural scholars who drew similarities between the morpho-typological qualities of these two projects. Pamela Karimi (2013) and Rana Habibi (2017), for instance, analysed the structure of public spaces in these projects and argued that the urban layout of Abadan had a substantial impact on the urban form of Kuy-e Chaharsad-Dastgah. Perhaps, a main resemblance between the two urban layouts was the presence of a central axis where most public facilities such as hospital, cinema, and parks were placed.

Although some similarities between these projects have been observed, Abadan did not determine the urban layout of Chaharsad-Dastgah which was informed by its own set of ideas. In his seminal research, "Abadan: planning and architecture under the Anglo-Iranian Oil Company", Mark Crinson (1997) showed that this company town was designed based on the idea of divining people into multiple social classes, mainly based on their cultural backgrounds and income levels, and nationalities. Crinson claimed that the families of high-income Iranian workers and of British expats had only access to certain public facilities. He argued that each social class was accommodated in a gated community and through a distinct housing typology (Figure 13). This approach to the design of housing an also be seen in most company towns developed for the workers of oil industry around the Persian Gulf, such as Al-Ahmadi in Kuwait (Fuccaro, 2013).

In contrast to Abadan that was designed as a company town, Chaharsad-Dastgah was a small city district. In fact, his residential neighbourhood provided housing for an emerging middle-class in Tehran from different ethnic and cultural backgrounds as well as income levels. The differences between Chaharsad-Dastgah and Abadan could also be observed from their urban typologies. For instance, in line with Howard's Garden City concept, all house-types in Abadan were provided with a front and back-yard; and they were placed as free-standing objects in a vast green area. In Chaharsad-Dastgah, however, a semi-closed block typology formed a boundary between public streets and private courtyards. Rather than promoting a hierarchical division, careful attention was paid to the integration of public spaces with the residential areas in Chaharsad-Dastgah. Arguably, these endeavours might be seen as a result of implementing a planning document that focused on modernising everyday life of Iranians, in Tehran.

\section{Modernising the everyday life}

Everyday life might be understood as a cultural way of engaging with the world, an elusive object, which is immediately present, but in flux (Harris, 1997). Thus, this cultural practice has root in traditions, and is ever-changing (Jacobs, 2003). Quoting the French poet Charles Baudelaire, Matei Calinescu also argued that modernising the concerns of everyday life with the immediate present is where the notion of modernity connotes "the paradoxical possibility of going beyond the flow of history through the consciousness of historicity in its most concrete immediacy" (Calinescu, 1987, p. 50). Thus, modernity can be seen as imaginative 

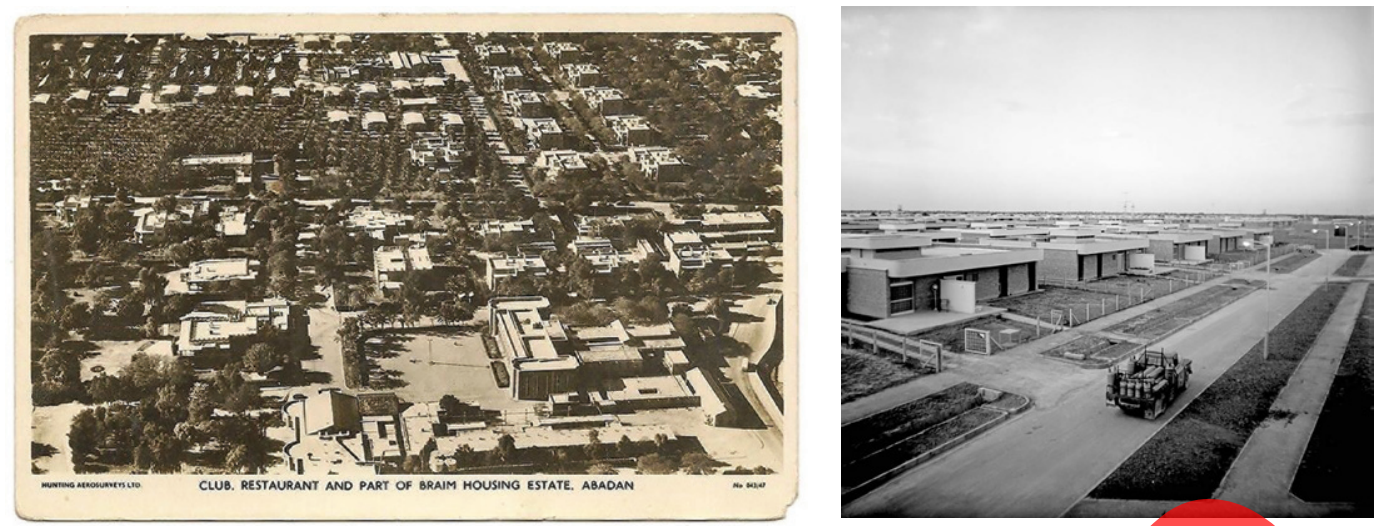

Figure 13. Various housing typologies for different working-class groups in Abadan (source: the Archive of Iran's National Oil Company)

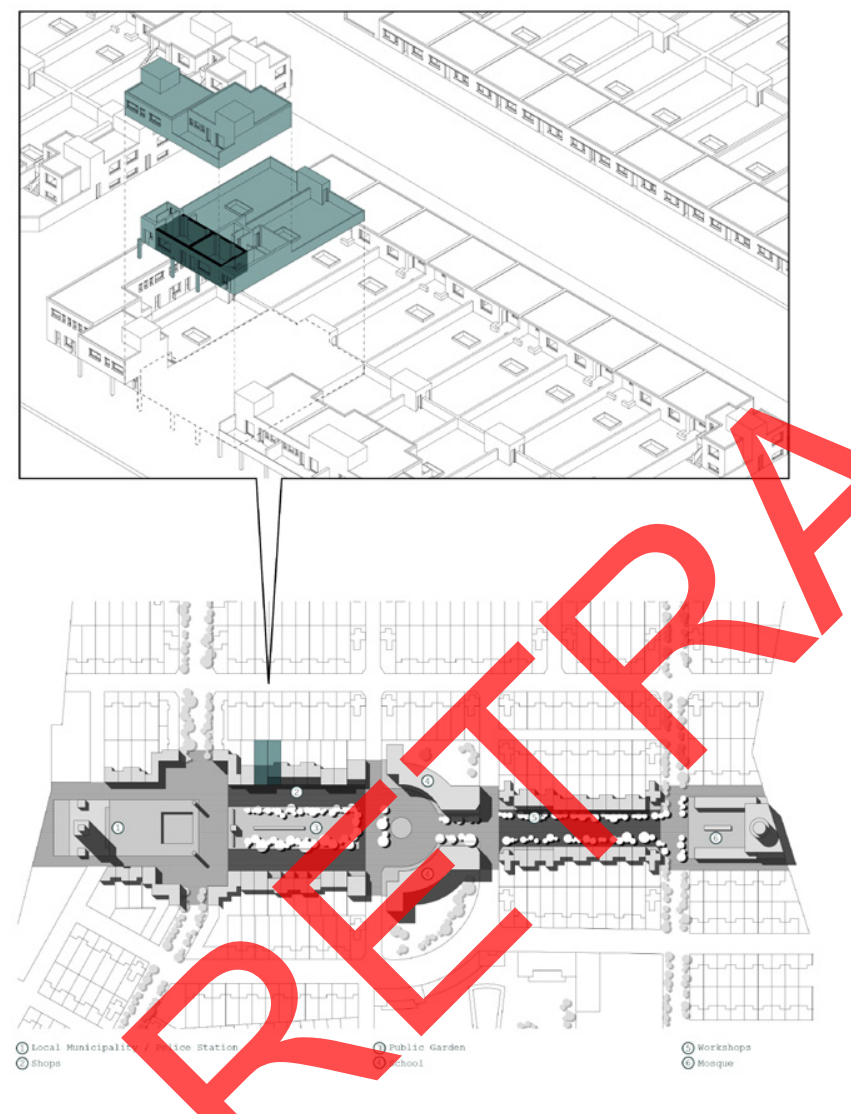

Figure 14. The shops on the ground level shaped the edge of the central plaza in Chaharsad-Dastgah. The dark-green indicates an example of the shop-house typology including a courtyard (light-green) behind and a dwelling unit (light-green) on top of the ground-bound shop (source: the authors)

creation, drama or adventure separated from tradition which is defined by a body of works and procedures to be imitated (Calinescu, 1987). In this view, modernising cultural practices is a way of creating self-consciousness and self-realisation of what is new and unknown, and recreating or reimagining particularities of what is old and familiar. This process of re-creation is traceable from the design and development of Chaharsad-Dastgah.

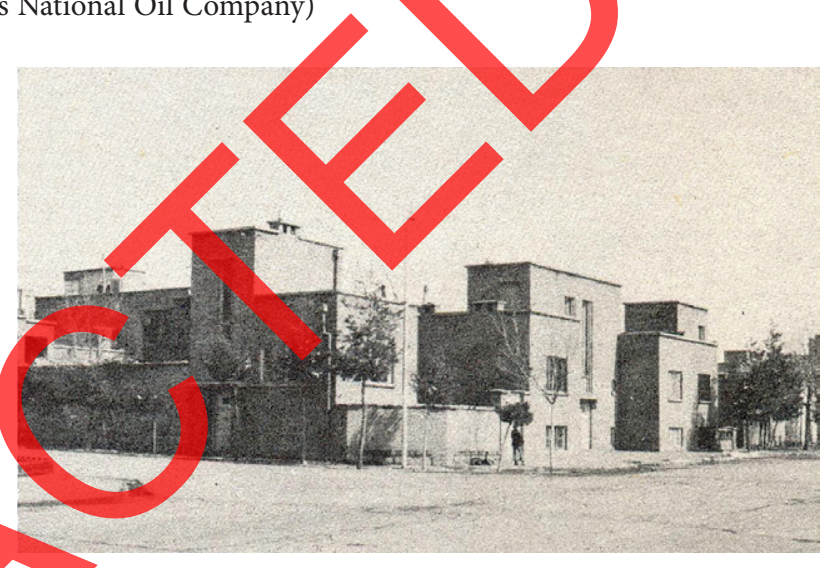

Figure 15. Articulated volume including a staircase, front door and a set of corridors (source: Honar va Memari, 3(10-11)

(1978), 125)

The urban layout of this housing project was designed based on the municipality's planning document, revised under the leadership of Ali Sadegh. As mentioned earlier, this document aimed to improve living conditions in urban areas, and to modernise many aspects of private and public life among the people of Tehran. This happened by prescribing regulations that focused on the design of urban spaces such as public squares and roundabouts, as well as of the facades facing the streets. For instance, the document proposed that the vacant lands adjacent to urban spaces have to be walled-off, and the façades of buildings facing streets needed to be materialised in harmony with adjacent buildings to form a well-organised street image for the city. Based on these new regulations, public squares and roundabouts should be surrounded with (work)shops and public buildings. It comes, thus, as no surprise that a series of shops and a group of public buildings such as school and post office shaped the edges of the central plaza, in this project (Figure 14).

Equal consideration was given to the design of private buildings as the face of buildings towards public spaces, all street-oriented façades were materialised with bricks; and the windows, openings, and sky-lines of each house were erected in harmony with the neighbouring buildings. Moreover, each dwelling type was constructed with an ar- 
ticulated building volume that included the entrance area, staircase, and front door (Figure 15). While this volume was set back from the streets, it maintained direct connection to public spaces. The street facades were further designed with large windows to create visual interactions between interior and exterior spaces. As requested in the planning document, these design decisions formed the basis for creating a monumental appearance as well as an organised image for streets. These decisions also became instrumental for exposing private indoor spaces, mainly kitchens and living rooms to the streets.

As mentioned previously, unveiling was a state-strategy to modernise the image of Iranian society. This strategy became a source of inspiration for many Europeaneducated architects to change the appearance of public spaces, largely seen as veiled, obscure, or enclosed, in Iran. Evidence of this movement might be found from several articles disseminated by the board members of the Association of Registered Iranian Architects (ARIA). These articles mostly praised the value of the compulsory unveiling act as a necessary condition for implementing social and spatial changes in cities. As observed and discussed by Bani-Masoud (2015) and Habibi (2017), Vartan Hovanesian (1960), an influential figure of the ARIA, saw the unveiling as the most progressive social reform in the country, which changed old-fashioned Iranian society and the everyday life of people in public spaces.

Hovanesian (1960) drew a relationship between the unveiling act and development of new housing models, in Tehran. To illustrate this, Hovanesian compared the physical appearance of traditional women with that of individual houses. In this comparison, female households were depicted with dark veils (chador) hiding themselves from public scenes, and traditional houses were demonstrated with high muddy walls that surrounded inner spaces, preventing visual connection to the public exterior; and, he claimed that before the unveiling act, no one was able "to break the bleakness of this sadness" and build a window or balcony from their living room towards the streets (p. 7). He argued that the unveiling paved $a$ way for Iranian architects to introduce new forms of living to society, specially by extroverting veiled spaces to the public.
Arguably, the kitchen became a main locus of unveiling private interiors, in Kuy-e Chaharsad-Dastgah. Traditionally, kitchens were considered as the realm of the female members of households in Iran, mostly designed as an isolated entity in traditional houses of ordinary people and with minimum exposure to private outdoor spaces (Houchang Esfandiar Chehabi, 2003). In Chaharsad-Dastgah, however, the kitchens were placed adjacent to the public streets, with large openings; so, the position of the kitchen in house layouts allowed housewives for visual interaction with public spaces, while cooking and performing indoor household activities; so, the kitchen became more integrated with the house layout and exposed to the public life.

Aside from the kitchen, some other private exterior spaces were also exposed to the streets. The architects designed the two-storey houses with balconies facing the public plaza, a strategy that would bring women in a direct contact with the public life (Figure 16). These exposures would be helpful to persuade women to go outside the realm of home and become involved in societal activities. In a similar way, the courtyards became more visible to neighbouring households, encouraging a new form of living among the residents. Contrary to traditional houses where the courtyard was protected with high-walls (mostly up to 3-meter high) from the eyes of strangers, in Chaharsad-Dastgah, the courtyards were bounded with low-walls, almost 1.5 meter high. While this design strategy would secure some extent of privacy and indicate the rivate domain of each individual dwelling, it would also enable the inhabitants to choose for either closing-off or opening-up their courtyards to and from their neighbours.

Unveiling some interior spaces might also be seen as an attempt to ensure a minimum standard of hygiene for the residents. To enable natural lighting and ventilation, the architects of Chaharsad-Dastgah designed not only the kitchens in a direct contact with outdoor spaces, but also service spaces including storage areas, bathrooms and toilets. In all dwelling types, the toilets and storage areas were placed in the courtyards; the bathrooms were either positioned in the courtyard or side-by-side with kitchens and they gained a small opening towards the streets. Aside from service spaces, all habitable rooms were designed
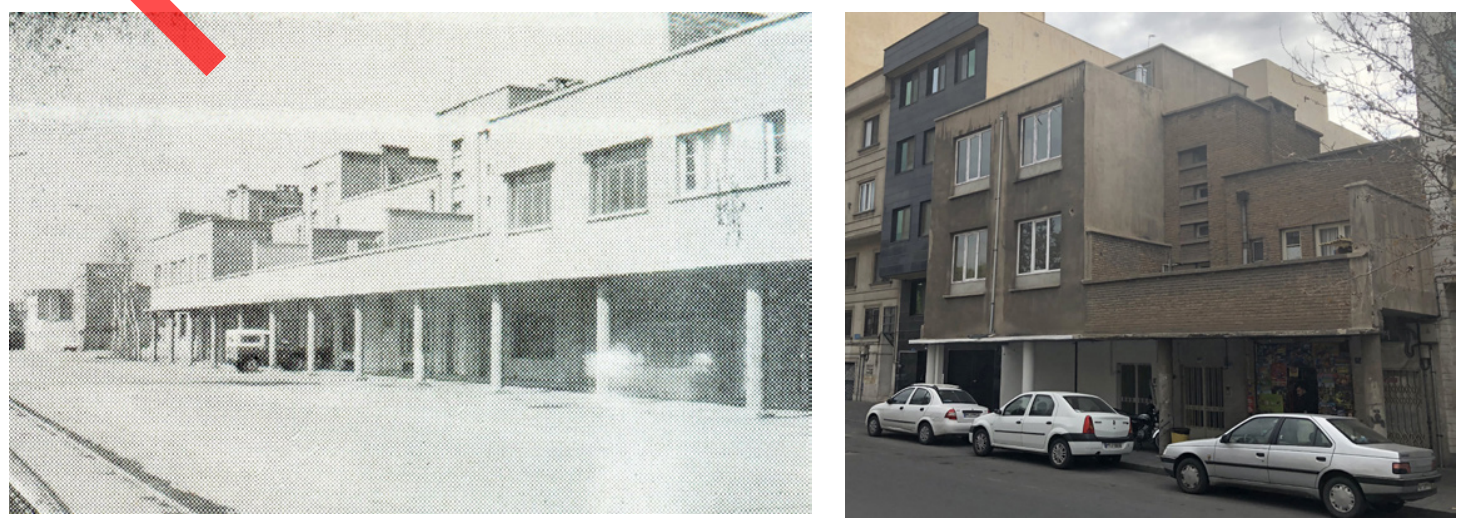

Figure 16. Two story houses were designed with balconies and terraces towards the public space (source: Honar va Memari, 3(10-11) (1978), 124 (top); and the authors (bottom)) 
with large windows to secure suitable access to natural light and fresh air, from the outside. As argued by the designers of the project, the orientation of houses was also chosen to optimise the sun-light penetration to interior spaces, and therefore, to ensure healthy living conditions in this project (Khoursand, 1946).

Providing a minimum standard of hygiene was not limited to merely providing exposure to natural ventilation of spaces, but also focused on the securing of all basic services and spacious interiors. All house types were designed with a minimum amount of 3 habitable rooms, aiming to reduce overcrowding at the household level. Moreover, plumbing and electricity was supplied for each unit, separately; and in the absence of a sewage system in Tehran, a septic tank was provided for each dwelling type (Adjdari, 1946c). A water storage in the form of a tower was also placed adjacent to the central plaza. This outstanding structure and its position in the urban layout might be seen as celebrating the access of future inhabitants to pure drinking water in this neighbourhood. Further, a public bath-house was designed in the centre to ease the access of residents to warm water for bathing. Accordingly, this housing project contributed to improve the living condition, sanitation, and health of non-elite Iranians; and it aimed to promote a notion of modern living among a group of low-income civil servants, in Tehran.

Introducing new institutional buildings and transforming the traditional administrative structure of neighbourhoods played a pivotal role in shaping and promoting a new public life, in Chaharsad-Dastgah. Traditionally, neighbour hoods (Mahalleh) were ruled by elder men (Rishsefieds) or religious leaders, in Iran. While they were responsible to collect tax on behalf of the state authorities, they also settled disputes among the neighbours and gathered donations from the rich merchants and families to build communal amenities, such as bath-houses, local schools, and mosques, in the neighbourhood. For providing social security, they authorised a group of outstanding residents, known as pahlavans or lutis who voluntarily patrolled the streets at night or at the moment of any tension In Chaharsad-Dastgah, nevertheless, this traditional administrative structure was radically changed; and the design of administrative buildings catered for a new form of urban governance.

In this residential neighbourhood, the local municipality and post office, constructed around the central plaza, replaced the role of traditional councils and elders; and the police station hosted semi-armed military forces to take responsibility for providing security and controlling any form of social unrest or tension within the neighbourhood. Further, two distinct structures were proposed for the construction of a primary school and small clinic. Perhaps, these public buildings were meant to promote the newly established pedagogical methods and healthcare system among the residents. Designing these urban elements in innovative building shapes and typologies might also be perceived as an attempt of the architects of Chaharsad-Dastgah, to symbolise the "modern" elements of a new urban life in Tehran.
The modernisation of everyday life was not limited to incorporating new architectural elements in the urban layout. Arguably, the design of this housing project was also an attempt to neutralise the socio-political lives of inhabitants in Tehran. In traditional urban fabrics of most Iranian cities, the Friday Mosque and religious buildings, such as Tekiyeh and Hosseyniyeh, were placed at the heart of the neighbourhood structure, used as a place for public gatherings (Herdeg, 1990). As opposed to this pattern, the only religious building in Chaharsad-Dastgah was a small mosque designed at the edge of the district, far from the central plaza and most communal amenities that would form the backbone of urban life in the neighbourhood. Further, an amphitheatre was constructed around the central roundabout to accommodate public gatherings. Arguably, this strategy might be seen as an attempt of the architects of Chaharsad-Dastgah to secularise the social order, public spaces, and urban life of the inhabitants, while using local references for the design.

\section{Local references and everyday life}

In earlier studies, scholars such as Pamela Karimi (2013), Hamed Khosravi et al. (2017), and Rana Habibi (2017) drew some parallels between the housing project of ChaharsadDastgah and local architectural culture in Iran. These studies mainly focused on the typological components of traditional houses and discussed how some of these components could be traced in Kuy-e Chaharsad-Dastgah. This section goes beyond just a typological analysis, and relies on the everyday experiences of people in Chaharsad-Dastgah. The process of design decision-making in Chaharsad-Dastgah illustrated a sensible attempt to incorporate some traditional premises of everyday life. This might be seen from the conscious choice of the architects of this project to design a single-family house type, rather than collective apartment typology. This choice was explained by Abbas Adjdari, one of the designers of the project, as a way of responding to the climate condition of Tehran and the cultural lifestyle of Iranians. Adjdari (1946c) defined the land and house ownership as a core of traditional housing systems in Iran that would enable the members of the households for future expansion and modification of the house. In this view, he argued that employing an apartment typology would create difficulties for selling. Further, while defining courtyards as the basic core of Iranian houses, Adjdari put a distinct emphasis on the ways people individually experienced and collectively used these private outdoor spaces. The designer's use of individual courtyards created a space with dual characteristics that catered for both private and collective encounters in the same enclosure.

This approach is noticeable in Adjdari's analysis. Adjdari (1946b) claimed that traditionally, Iranian families spend most of their time together in "private outdoor spaces": the courtyards. He highlighted this as one of the primary parameters that should distinguish Iranian dwelling design from projects in the European context, where the use of public outdoor space was possible due 
to a culture of collective outdoor activity. It is thus not surprising why Adjdari argued that Western people are able to live in apartments with shared facilities, such as common laundry, kitchen, and bathrooms, while Iranians are family-oriented and keen to live in individual houses with a courtyard. Adjdari (1946b) pointed out that "for the moment, the apartment typology and the notion of collective living could not easily or successfully be adapted to Iranian ways of living; and therefore, rather that imitating Europeans, we need to find a compromise which would also suit Iranian lifestyles." (p. 52)

Arguably, this compromise might be found in the provision of multiple private outdoor spaces. All the dwelling types were designed with a courtyard on the ground level, as mentioned earlier; but interestingly, the two-storey houses were also constructed with balconies facing the public spaces and private courtyards. The balconies provided private exterior spaces for habitable rooms above the ground level. Similar to traditional neighbourhoods where the roof of houses was used as a platform by women for watching man-lead ceremonies in public spaces, the street-faced balconies of Chaharsad-Dastgah became a place for observing public events on the plaza and streets. While exposing the private exterior spaces might be seen as a result of the unveiling act, this exteriorising increased the chance of encounter between the female members of households and the general public, under their control and desires. The balconies were visually protected from their immediate neighbours with a party wall (2-meter high) and from the streets with a high parapet, as shown in Figure 16. Thus, women gained the opportunity to maintain and control their privacy, while using balconies that were exposed to the public life.

In the process of unveiling, interior spaces were also exposed to the public exterior through large windows or balconies. Interestingly, however, the courtyard remained as the private outdoor room in the dwelling layout. Accessible to all interior spaces through a veranda (Iwan), the courtyards were designed deep, at the back side of the construction lot, that would allow high heat losses for ventilation. As mentioned earlier, these courtyards were separated from public outdoor spaces by being placed at the back-side of dwelling plots, but connected to the streets through a network of corridors and stairs. Comparable to traditional houses, this access system created a gradation of public-private separation and transition in the dwelling layouts of Chaharsad-Dastgah. More importantly, this access system provided certain extent of autonomy for the courtyards and all habitable spaces within the house layout (Figure 17)

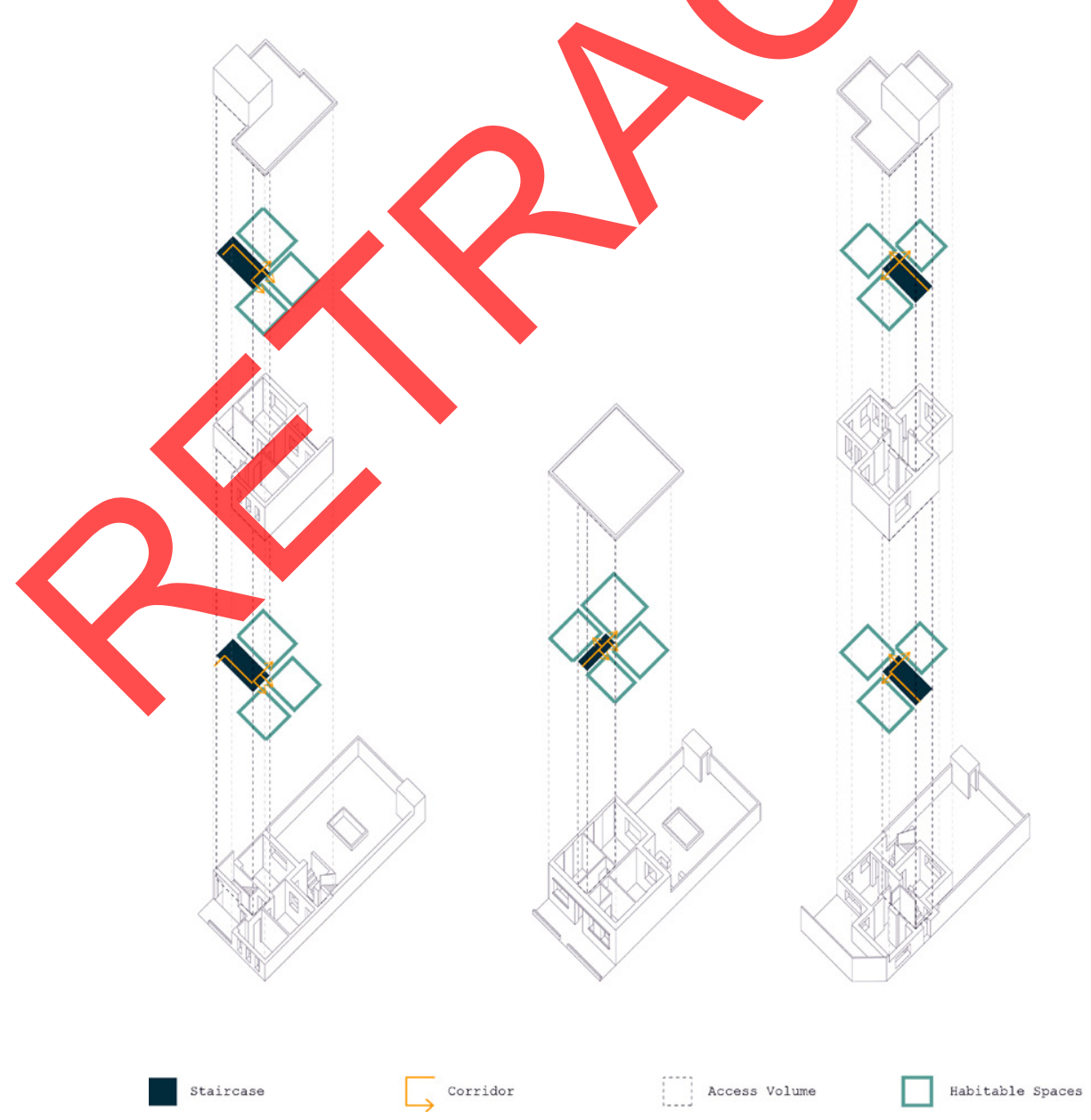

Figure 17. The access system of houses in Chaharsad-Dastgah provided some extent of autonomy for the courtyards and all habitable spaces within the house layout (source: the authors) 
The placement of access system as an autonomous entity in the spatial layout of dwellings enabled the inhabitants to use each habitable room, interchangeably. As mentioned earlier, the entrance area, staircase, corridors, and front door were grouped together in a distinct building volume, which was placed as a filter between the habitable spaces, the courtyard, and the street. In so doing, not only every dwelling unit gained an independent access to the public space, but also each habitable room and the courtyards, as shown in Figure 17. Similar to most traditional houses, this provided different layers of privacy and publicity for each space, enabling the inhabitants to rent or share some rooms, when needed, as well as to use each room without intersecting the others, for their daily activities. To accommodate different lifestyles, these rooms were also designed with similar spatial proportions that would allow people to use the interior spaces in multiple ways and interchangeably.

For the construction, the architects of ChaharsadDastgah employed local materials and building techniques that were dependent on available resources. They proposed sand-lime bricks for load-bearing walls and facades to be placed on concrete footings. They also employed supporting columns made by in-situ concrete and steel I-beams to create the slabs. The empty space between the beams was filled with brick-made barrel-vault, and it was covered with brick tiles. In fact, the choice of this low-tech building system enabled the architects to hire unskilled workers, local masons, and traditional builders (Mimars). Moreover, it allowed the Mortgage Bank to build small brick factories for producing needed materials, efficiently and in a large-scale, during the construction process of this experimental housing project

The housing typology of Chaharsad-Dastgah also promoted a notion of collectiveliving among the residents. The designers carefully divided each urban block into smaller lots, enabling the Mortgage Bank to provide loans for future inhabitants based on the size of the individual plots. However, rather than proposing (semi)detached single-family houses on the private properties, the ar-

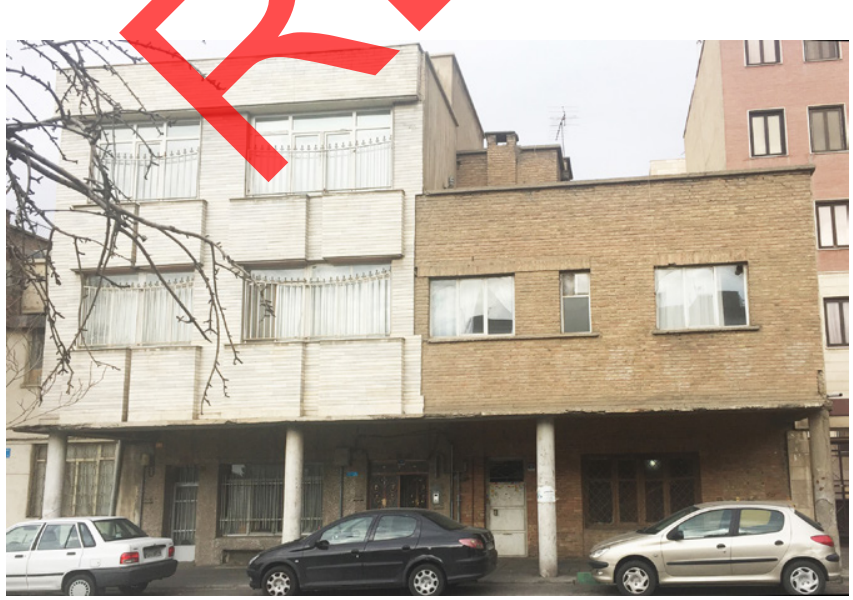

chitects designed a set of low-rise row-house typologies, juxtaposed in variety of combinations, to form the urban blocks. This allowed the architects to design load-bearing walls that were shared by multiple dwelling units, and construct the buildings with minimum exterior surface. While provision of party walls, shared facades, and communal staircases in two-story house types were strategies to reduce the cost of construction (Khoursand, 1946), they also formed a basis for collaboration among the residents. Therefore, it comes as no surprise to see that the residents of each group of row-houses or urban block discussed and negotiated possibilities for individually using or collectively maintaining the communal areas of staircases, and for implementing any modifications in the structure or street façades of buildings, with their neighbours (Figure 18).

\section{The growth and change of Chaharsad-Dastgah}

Multiple forms of collaboration among the neighbours brought about changes in the urban layout of this project. This was observed by the authors, in particular from the modification of the courtyards. For instance, neighbours with a family relationship or strong friendship bound chose to demolish the walls between their private courtyards. In so doing, they not only enlarged the size of their courtyards for some gathering or collective activities, but also repositioned them in the larger body of the neighbourhood. On the contrary, some neighbours opted to completely fence-off their courtyards with higher walls (Figure 19). In so doing, they aimed to increase the visual privacy from their neighbouring houses, and to expand their living areas towards the courtyard.

Arguably, the autonomy of access to the courtyard and all interior spaces enabled the expansion of houses, incrementally. As mentioned earlier, each dwelling type included a minimum amount of three habitable rooms with a courtyard, to be built on different plot size. These building lots were designed with 7.5-meter width and 20 to 30-meter depth, ranging from 140 to 200 square meters. The built mass of each type was to occupy at most $50 \%$ of

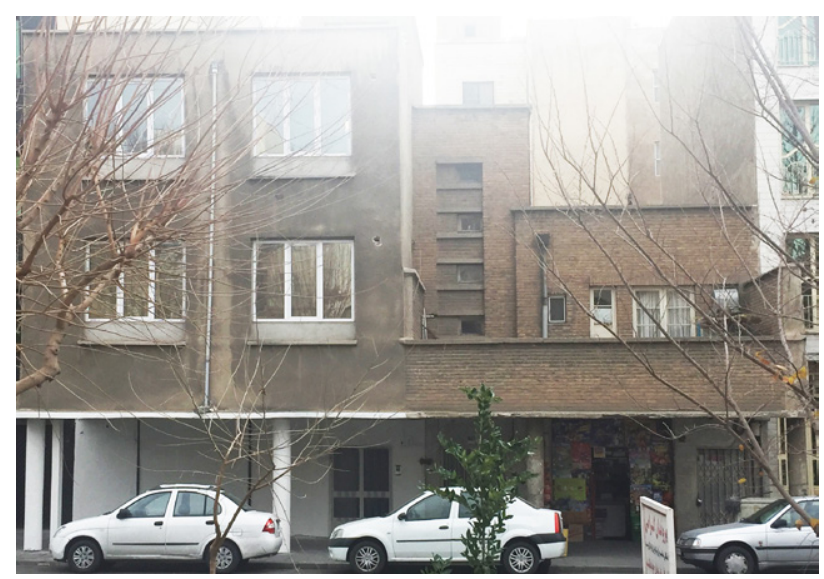

Figure 18. A few examples of changes implemented in the façade and structure of buildings. Noticeably, the new openings and windows were placed in the same height and comparable proportions, in relation to the neighbouring houses (source: photograph by the authors) 

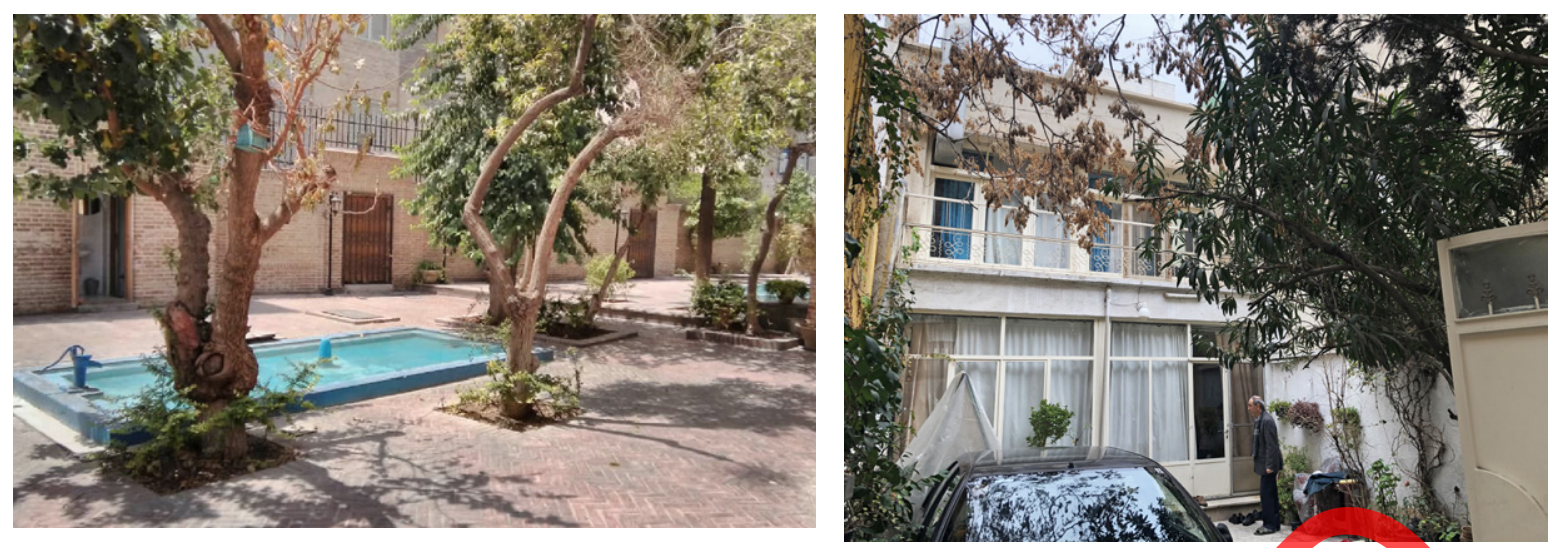

Figure 19. An example of changes made in the layout and size of the private courtyards where sone neighbours chose to demolish the walls between their outdoor spaces, to create a collective courtyard (top), and an example of a typical courtyard in Chaharsad-Dastgah that is completely fenced-off by its owners (source: photograph by the authors)

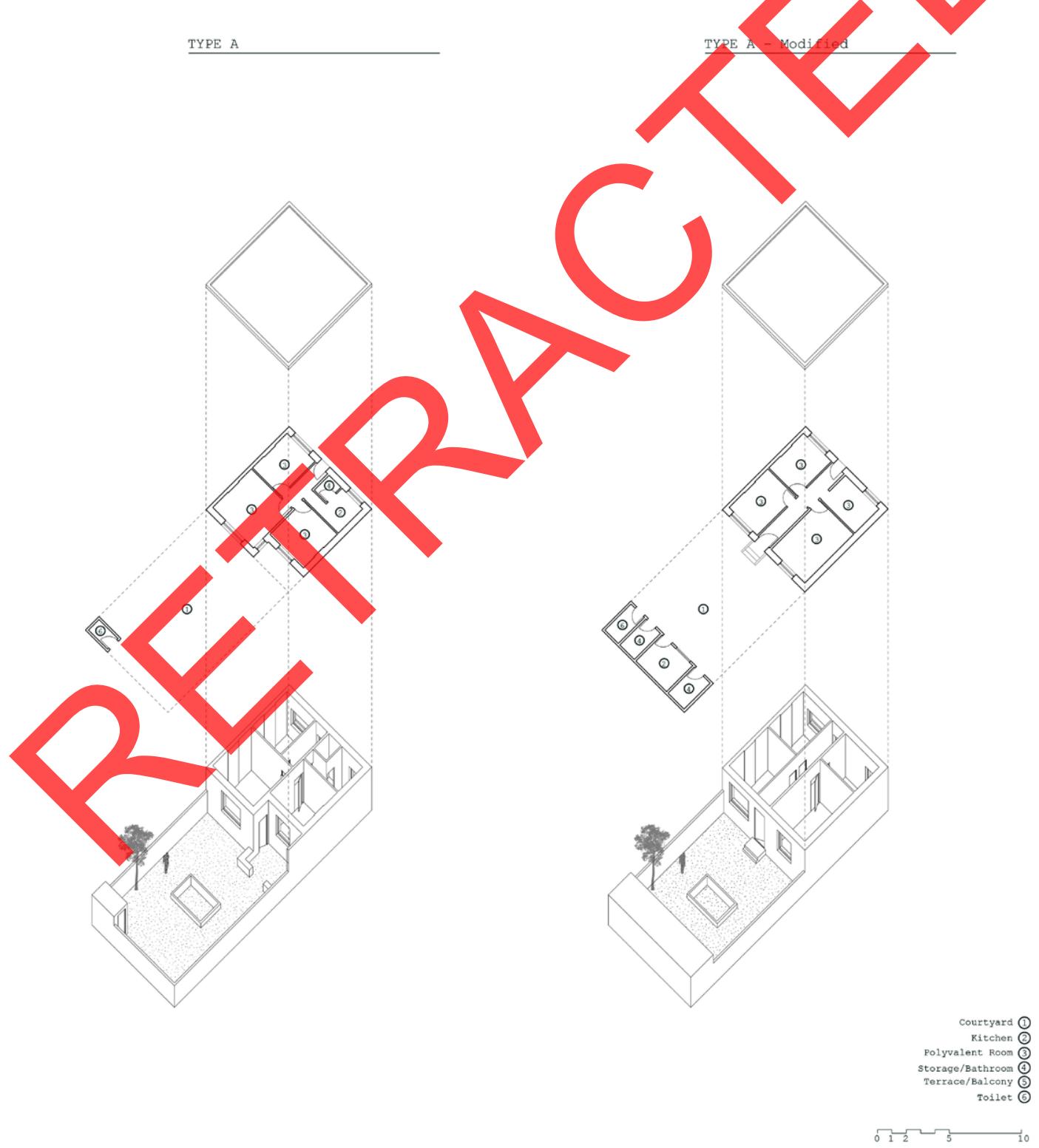

Figure 20. A typical one-story house of Chaharsad-Dastgah, after the adaptation of the house layout and courtyard (source: drawn by the authors, based on the documentation of some changes in the houses of Chaharsad-Dastgah that was initially gathered in an unpublished report of Iran's Ministry of Housing and Urban Development, prepared by Khadijeh Kia Kajouri, in 1972) 
the smallest construction lot, a strategy that kept the rest of the property intact as the courtyard. Based on the space needs of the family, extra rooms were erected, little by little over time, on one or two sides of the courtyard (Figure 20 ). While the courtyard played a crucial role as an unbuilt private outdoor space in accommodating growth and change in the spatial layout of individual houses, a big part of the courtyard in the majority of cases remained intact and was cultivated as a small garden. This can be seen from an aerial image of the project, where the courtyards, collectively and individually with the surrounded building mass, resemble a form of traditional Iranian courtyardgarden houses: the Khaneh-Bagh (Figure 21).

The construction system also enabled growth and change of houses in Chaharsad-Dastgah. Essential to this logic was the use of cavity party walls that provided some extent of autonomy for structural and spatial changes in each house. This structural feature also became instrumental in future development of the project, which can be seen from different forms of mid-rise residential buildings erected to replace one- and two-story individual houses

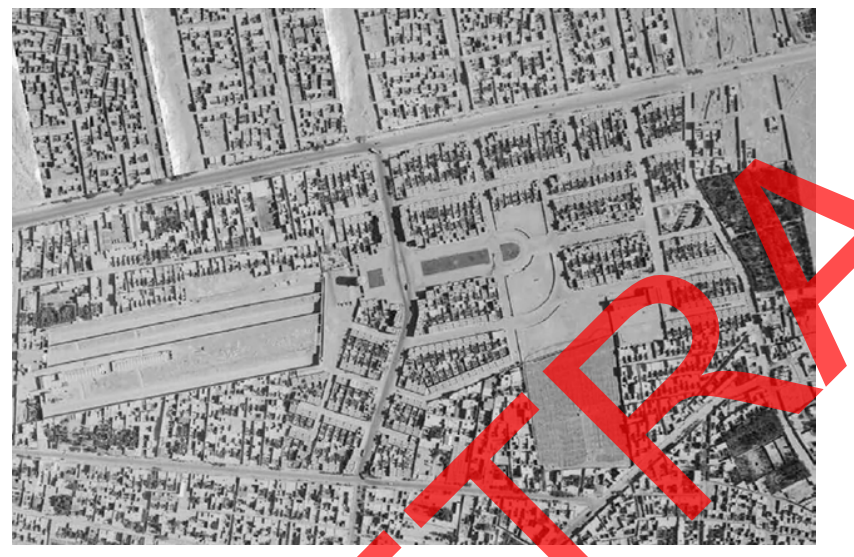

Figure 21. The aerial picture of Chaharsad-Dastgah showing while the houses underwent a series of changes, the courtyards still largely formed the heart of each house (source: Iran's

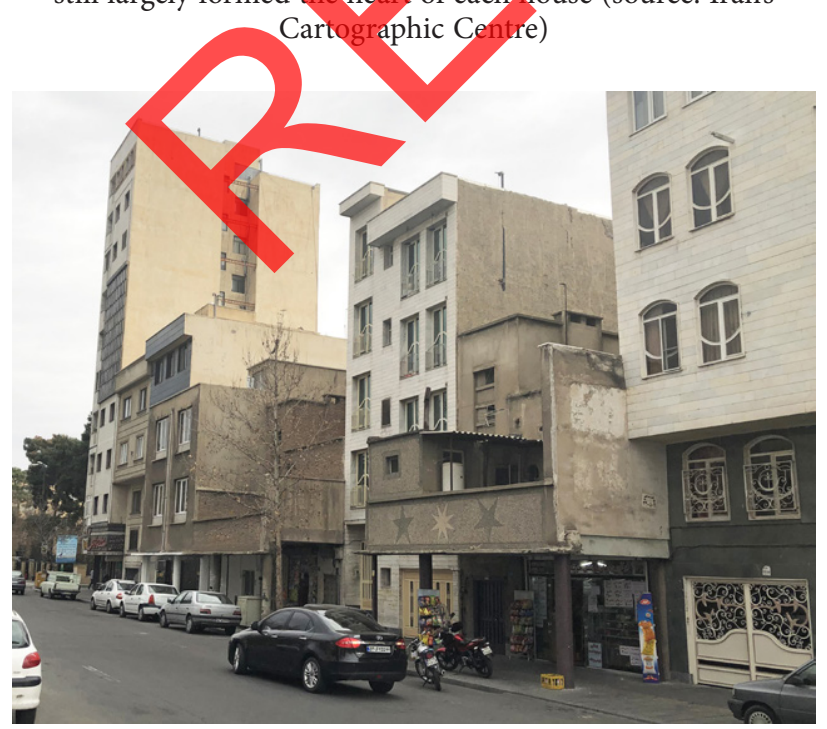

(Figure 22). This move radically transformed the well-organised image of public spaces in this project; but, it also embodied the idea of the experimental housing model to become responsive to ever-changing needs of their inhabitants, forming a strong feeling belonging to the place.

\section{Conclusions}

Kuy-e Chaharsad-Dastgah was a primary attempt of both the Iranian government and modernist architect to disseminate a notion of "modern" living among ordinary people, in Tehran. In fact, this experimental housing model illustrated "an instrument of nation-building in an attempt to gain the allegiance of the new citizenry" in the Middle East, as Nezar Al-Sayyad (2008) put it (p. 257). Aside from being an attempt for reconstructing Iranian identity, this project also aimed to improve the standards of living and accommodate large number of low-income civil servants in Tehran In this article, we demonstrated how this housing model both modernised many aspects of private and public life, and recreated certain vernacular patterns of inhabitation, such as the traditional Iranian house, in their most concrete immediacy. In this process of re-creating, the compulsory unveiling became instrumental for "inventing traditions", as Eric Hobsbawm and Terence Ranger (2012) put it, enabling a group of modernist Iranian architects to reconceptualise the ideal form of living, the courtyard house, for large-scale housing production.

The revised version of the 1941 planning document, enhanced by modernist Iranian architects, also played a vital role in modernising the everyday life of people. Incorporating institutional buildings, such as a police station and local municipality, in the urban layout of ChaharsadDastgah changed traditional socio-spatial relations within this neighbourhood. In addition, introducing public spaces such as streets and squares in new forms and functions contributed to stimulating outdoor public activities among the residents. Designing a row/block typology was

Figure 22. Some examples of apartment buildings constructed by the house owners in Chaharsad-Dastgah (source: photograph by the authors)

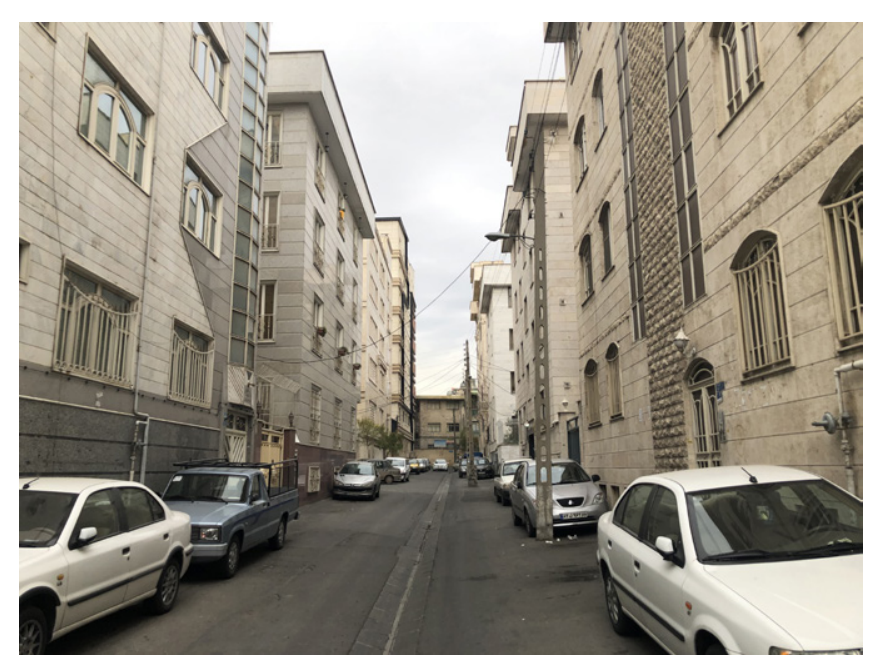


also a strategy to create an organised image towards public spaces, as required by the planning document. The built masses were placed on the edge of the streets, creating a strong distinction between public and private outdoor spaces. Interestingly, this distinction enabled the residents to develop and modify the unbuilt/vacant land behind their individual houses, the courtyards, based on their new needs, without changing the image of public spaces.

The process of promoting architectural modernity in Chaharsad-Dastgah was based on a careful deconstruction of traditional values. While interior spaces such as the kitchen were subjected to change in the dwelling layouts to introduce a new way of living in this process, the private courtyards and outdoor spaces became a locus of tensions between local and universal ideals. These tensions, we contended, were resolved through the paradoxical nature of the courtyard that would allow for both self-realising what is new and unknown as well as for resistance to universalising tendencies towards homogenisation. This results from the adaptability inherent in the core conception of the courtyard house type. As the architectural historian, Michael Dennis (1986), observed, the exact function, location and treatment of the courtyard in this house type have been adapted over time to respond to specific contextual circumstances, but regardless of its particular spatial and formal features.

In the case of Chaharsad-Dastgah, the courtyard cre ated a space with dual characteristics. While the interna layouts of houses were unveiled to the public, the courtyards remained invisible from the streets. These individual courtyards were also surrounded with walls. However, by positioning these courtyards together, back-to-back at the heart of the urban blocks, they became more open and visible to the surrounding neighbours, yet another act of unveiling. The low-walls enabled the inhabitants to gain visual access to their neighbours' courtyards. In some cases, they were afforded the opportunity to cluster the courtyards together with collective access to one another, or to use them for the expansion of their habitable spaces. This transformation of the traditional courtyard introduced a careful balance in the project between traditional premises of everyday life and the process of modernisation. In later residential projects in Iran, however, this balance seems to be lost, most of the time by not recognising the significance of the courtyard type in creating a co-existence between private and public outdoor urban life that is at the core of everyday patterns of inhabitation, in Iran.

\section{Acknowledgements}

We are grateful for the valuable material provided by the National Archive and Library of Iran. Special thanks to Federico Pellegrini and Robby Stubbs for their invaluable contribution during the development of this research. We are also very grateful for the insightful comments of reviewers.

\section{References}

Abadan: Az Nazar-e Sakhteman va Shahrsazi. (1946). Abadan: in view of architecture and urbanism. Arshitekt, 1(4), 141-145.

Abrahamian, E. (1982). Iran between two revolutions. New Jersey: Princeton University Press.

Abrahamian, E. (2008). A history of modern Iran. Cambridge: Cambridge University Press. https://doi.org/10.1017/CBO9780511984402

Adjdari, A. (1946a). Masa'ele Tahiyeh Maskan dar Tehran va Shahrestanha [Problems of housing in Tehran and other Iranian cities]. Arshtekt, 1(1), 15-16.

Adjdari, A. (1946b). Masale-ye Tahiy-e Maskan dar Tehran va Shahrestan-ha [The problem of housing in Tehran and the other Iranian cities]. Arshitekt, 1(2), 51-52.

Adjdari, A. (1946c). Sakhteman-e Khaneh-haye Arzan dar Iran [Building Low-Cost Housing in Iran]. Arshitekt, 1(4), 125-133.

Alsayad, N. (2008). From modernisation to globalisation: the Middle East Context.InS. Isenstadt \& K Rizvi (Eds.), Modernism and the Middle East: architecture and politics in the Twentieth Century. Seattle. University of Washington Press.

Amin, C. M. (2002). The making of the modern Iranian Woman: gender, state policy, and popular culture, 1865-1946. Gainesville: University Press of Florida.

Ansari, A. M. (2003). Modern Iran since 1921: the Pahlavis and after. London: Pearson Education.

Arin Pour, Y. (2000). Az Saba Ta Nima: Tarikh-e 150 saal adabe parsi. Tehran: Sherkat-e Sahami-e Ketabhay-e Jibi.

Atabaki, T., \& Zuurcher, E. J. (2004). Men of order: authoritarian modernisation under Ataturk and Reza Shah. London and New York: I.B. Tauris.

Badie, N. (1946). Naghshebardari va Tarh-e Eslahi Shahr-e Tehran [Mapping and Redesigning the City of Tehran]. Arshitekt, 1(1), 18-19.

Banani, A. (1961). The Modernization of Iran, 1921-1941. Stanford: Stanford University Press.

Bani Masoud, A. (2015). Memari Moaser Iran. Tehran: Nashr-e Honar-e Memari Gharn.

Calinescu, M. (1987). Five faces of modernity. Durham: Duke University Press.

Catanzaro, C. (2014). Policy or Puzzle? The fiundation of the University of Tehran between ideal conception and pragmatic realisation. In B. Devos \& C. Werner (Eds.), Culture and Cultural Politics Under Reza Shah: The Pahlavi State, New Bourgeoisie and the Creation of a Modern Society in Iran, 18, 37-54. London: Routledge.

Chehabi, H. E. (1993). Staging the emperor's new clothes: dress codes and nation-building under Reza Shah. Iranian Studies, 26(3/4), 209-229. https://doi.org/10.1080/00210869308701800

Chehabi, H. E. (2003). The Westernization of Iranian culinary culture. International Society of Iranian Studies, 36(1), 43-61. https://doi.org/10.1080/021086032000062875

Crinson, M. (1997). Abadan: planning and architecture under the Anglo- Iranian Oil Company. Planning Perspectives, 12(3), 341-359. https://doi.org/10.1080/026654397364681

Crinson, M. (2003). Modern architecture and the end of empire. Aldershot, Hants, England: Ashgate.

Cronin, S. (2003). The making of modern Iran: state and society under Riza Shah 1921-1941. London: Routledge Curzon. https://doi.org/10.4324/9780203423141

Dennis, M. (1986). Court \& Garden: From the French hotel to the city of modern architecture. Cambridge, Massachusetts: The MIT Press. 
Duncan, M. (1973). The modern courtyard house: a history. London: Lund Humphries for the Architectural Association.

Fuccaro, N. (2013). Histories of oil and urban modernity in the Middle East (Vol. 33). Durham, NC: Duke University Press. https://doi.org/10.1215/1089201X-2020327

Gastil, R. (1958). Middle class impediment to Iranian modernisation. Public Opinion Quarterly, 22(3), 325-329. https://doi.org/10.1086/266797

Gharipour, M. (2016). The historiography of Persian architecture (Vol. 29). London: Routledge.

Grigor, T. (2009). Building Iran: modernism, architecture, and national heritage under the Pahlavi Monarchs. New York: Periscope Publishing.

Grigor, T. (2014). The king's white walls: Modernism and bourgeois architecture. In B. Devos \& C. Werner (Eds.), Culture and cultural politics under Reza Shah: The Pahlavi State, New Bourgeoisie and the creation of a modern society in Iran, 18, 95-118. London: Routledge.

Habibi, R. (2017). The institutionalization of modern middle class neighborhoods in 1940s Tehran - case of Chaharsad Dastgah. Cities, 60, 37-49. https://doi.org/10.1016/j.cities.2016.07.006

Habibi, S. M. (1999). Az Shar ta Shahr: Tahlili Tarikhi az Mafhume Shahr va Simaye Kalbudie an Tafakkor va Taassor. Tehran: University of Tehran Press.

Harris, S. (1997). Everyday architecture. In S. Harris \& D. Berke (Eds.), Architecture of the Everyday (pp. 1-8). New York: Princeton Architectural Press.

Herdeg, K. (1990). Formal structure in Islamic Architecture of Iran and Turkistan. New York: Rizzoli.

Hobsbawm, E., \& Ranger, T. (Eds.). (2012). The invention of tradition. New York: Cambridge University Press. https://doi.org/10.1017/CBO9781107295636

Hoodfar, H. (2000). Iranian women at the intersection of citizenship and the family code, the perils of "Islamic Criteria". In S Joseph (Ed.), Gender and citizenship in the Middle East (pp. 287-313). Syracuse, NY: Syracuse University Press.

Hovanesian, V. (1960). Reza Shah Mazhar Abadani va Omran [Reza Shah as the symbol of progress]. Memari Novin, I(1), 4-9.

Hovanesian, V. (1946). Masael-e Memari dar Iran [Architeccural issues in Iran]. Arshitekt, 14), 139-140.

Jacobs, J. M. (2003). Tradition is (not) modern: deterritorializing globalization. In N. Alsayyad (Ed.), The end of tradition? (pp. 29-45). London and New York: Routledge.

Karimi, P. (2013). Domesticity and consumer culture in Iran interior reyolutions of the modern era. London and New York: Routledge. https://doi.org/10.4324/9780203072905

Khorsand, M. (1946). Tarikheheh Sakhteman Khanehaye arzan gheyamt dar europa [A History of Low-cost Housing Development in Europe]. Arshitekt, 1(4), 120-125.

Khosravi, H. (2015). Discreet austerity: notes on Grabriel Guevrekian's gardens. Cloud-Cuckoo International Journal of Architectural Theory, 20(34), 197-212.

Khosravi, H., Djalali, A., Marullo, F., Frausto, S., \& Riedijk, M. (2017). Tehran: life within walls: a city, its territory, and forms of dwelling. Berlin: Hatje Cantz Verlag.

Khoursand, M. (1946). Khane-haye arzan-e Kuy-e ChaharsadKhaneh [The Low-cost Housing of Chaharsad-Dastgah]. Arshitekt, 1(4), 133-135.

Kiani, M. (2013). Memari Dore Pahlavi Aval: Degarguni Andisheha, Peydayesh va Sheklgiri Memari Doreh 20 saleh Moaser Iran 1299-1320. Tehran: Markaz Chap Nashr Shahr.

Kianouri, N. (1946). Tajdid Sakhteman-haye Kharab Shode dar Etehad Jamahid Shoravi [Reconstruction of Buildings in Soviet-Union]. Arshitekt, 1(2), 58-63.
Koliat. (1946). The Overview. Bank-e Rahni, 2, 22(10), 63-70.

Madanipour, A. (1998). Tehran: the making of a metropolis. Chichester: John Wiley \& Sons.

Marefat, M. (1988). Building to power: architecture of Tehran 1921-41. Massachusetts Institute of Technology, Boston.

Memarian, G. (1994). Ashnaee ba memari maskuni Irani: gunehshenasi darungara. Tehran: Iran University of Science and Technology.

Moghadam, V. M. (2006). Materialist policies versus women's economic citizenship? Gendered social policy in Iran. In S. Razavi \& S. Hassim (Eds.), Gender and social policy in a global context: uncovering the gendered structure of "the social" (pp. 87-109). New York: Palgrave Macmillan. https://doi.org/10.1057/9780230625280 4

Mohamad Abadi, A. M. (1946). Mozu Tahiyeh Masaleh [The issue of building materials]. Arshitekt, 1(4), 136.

Mokhtari Taleghani, E. (2011). Miras-e memari-e modern-e Iran. Tehran: Fekr-e Nou

Mumford, E. P. (2000). The CIAM discourse on urbanism, 19281960. Cambridge: MIT Press.

Nilghaz, M. (2009). Vazayef Baladiyeh Tehran [The duties of the municipality of Tehran]. Payam Baharestan, 1(4), 1005-1044.

Rabbat, N. (2010). The courtyard house: from cultural reference to universal relevance. Burlington, USA and Surrey, England: Asligate Publishing Limited.

Roberts, G. (2006). Chelsea to Cairo: "Taylor-Made" water through eleven reigns and in six continents: a history of John Taylor \& Sons and Their Predecessors. London: Thomas Telford. https:/doi.org/10.1680/ctc.34112

Rostan-Kolayi, J., \& Matin-Asgari, A. (2014). Unveiling ambiguities: revisiting 1930s Iran's kashf-i hijab campaign. In S. Cronin (Ed.), Anti-veiling campaigns in the Muslim world: gender, modernism and the politics of dress, 31, 121-148. London: Routledge.

Sheibani, M. A. (1946a). Khaneh-ye Khub [A Good Home]. Arshitekt, 1(4), 148.

Sheibani, M. A. (1946b). Peidayesh Fekr-e Tahiyeh Sakhtemanhaye Daste-jami arzan baha dar Iran [The Idea of Developing Low-cost Housing in Iran]. Arshitekt, 1(1), 28.

\section{Appendix}

\section{Glossary}

ARIA: the Association of Registered Iranian Architects Arshitekt: the Iranian Journal of Architect

Bank-e Rahni: the Mortgage Bank

Chador: traditional Iranian women's veil

De Stijl: a group of Dutch modernist architects

Hejab: Islamic veil

Iwan: veranda

Khaneh-Bagh: the traditional Iranian courtyard-garden house type

Mahalleh: the traditional neighbourhoods in Iran

Mimars: traditional builders

Pahlavans/Lutis: a group of outstanding residents, who voluntarily patrolled streets

Rishsefied: elder man

Tekiyeh and Hosseyniyeh: two types of religious buildings 